\title{
Tectonic inversion of compressional structures in the Southern portion of the Paramirim Corridor, Bahia, Brazil
}

\author{
Inversão tectônica de estruturas compressionais da \\ porção Sul do Corredor do Paramirim, Bahia \\ Simone Cerqueira Pereira Cruz ${ }^{1 *}$, Fernando Flecha Alkmim², \\ Johildo Salomão Figueiredo Barbosa ${ }^{1}$, Ivo Dussin ${ }^{3}$, Luiz César Corrêa Gomes ${ }^{1}$
}

\begin{abstract}
The Paramirim Corridor represents the maximum inversion zone of the Paramirim Aulacogen. Reverse-to-reverse dextral shear zones and various types of folds dominate such corridor. These structures reflect a stress field that is WSW-ENE oriented, developed in units of Aulacogen basement, as well as in the Lagoa Real Intrusive Suite, of Statherian age, in Espinhaço and São Francisco supergroups, of Statherian-Tonian and Cryogenian ages, respectively, and in the Macaúbas-Santo Onofre Group, of Tonian age at the most. A rich collection of extensional structures truncate compressional structures of the Paramirim Corridor, characterized by normal shear zones and foliation, which is sometimes mylonitic, down-dip stretching lineation, drag folds, traction fractures and S/C structures. In these shear zones, quartz occurs truncated by the foliation, while feldspars are fractured and altered to white mica. Distribution of the quartz c-axes is at a maximum of $14^{\circ}$ from the $\mathrm{Z}$-axis. Thus, it suggests that the deformation activated mainly the basal glide planes in the $<a>$ direction. The paleostress study using the Win-Tensor software demonstrated that the regimen ranged between radial and pure distention. The $S_{1}$ direction oscillated around a vertical trend, while $s_{3}$ was sub-horizontal, with a predominant $\mathrm{N} 230-050^{\circ}$ direction. $\mathrm{Ar}-\mathrm{Ar}$ ages in biotite obtained from the extensional shear zones ranged from 480 and $490 \mathrm{Ma}$. Together, data obtained for the structures associated with the late extensional regimen described in the present study suggest that its nucleation is associated with distal and brittle-ductile sectors of the gravitational collapse zone of Araçuai-West Congo Orogen. KEYWORDS: Shear Zone; Paramirim Corridor; Gravitational Collapse.
\end{abstract}

RESUMO: O Corredor do Paramirim representa a zona de máxima inversão do Aulacógeno do Paramirim, no qual predominam zonas de cisalhamento reversas-reversas destrais e vários tipos de dobras. Essas estruturas refletem um campo de tensäo segundo WSW-ENE, os quais se desenvolvem nas unidades de embasamento do Aulacógeno, assim como na Suite Intrusiva Lagoa Real, de idade estateriana, nos supergrupos Espinhaço e São Francisco, de idades estateriana-toniana e criogeniana, respectivamente, bem como no grupo Macaúbas-Santo Onofre, de idade máxima toniana. Um rico acervo de estruturas extensionais truncam as estruturas compressionais do Corredor do Paramirim, sendo caracterizado por zonas de cisalhamento normais e foliaçäo, por vezes milonítica, lineação de estiramento down dip, dobras de arrasto, fraturas de tração e estruturas S/C. Nessas zonas de cisalhamento, o quartzo ocorre truncado pela foliação, enquanto o feldspato apresenta-se fraturado e alterado para mica branca. A distribuição dos eixos-c de quartzo encontra-se no máximo a $14^{0}$ do eixo $Z$. Portanto, isso sugere que a deformação ativa os planos basais <a>. O estudo de paleotensão utilizando o programa Win-Tensor demonstrou que o regime variou entre a distensão radial e a pura. A direção de s oscilou ao redor da vertical, enquanto que $s_{3}$ é sub-horizontal, com predominância da direçâa N230-050. Idades Ar-Ar em biotita obtidas nas zonas de cisalhamento extensionais variou entre 480 e $490 \mathrm{Ma}$. Em conjunto, os dados obtidos para as estruturas associadas com o regime extensional tardio descrito neste trabalho sugerem que a sua nucleação está relacionada com os setores distais, rúptil-dúcteis, da zona de colapso gravitacional do Orógeno Araçuai-Oeste Congo.

PALAVRAS-CHAVE: Zonas de Cisalhamento; Corredor do Paramirim; Colapso Gravitacional.

${ }^{1}$ Research and Graduation Program in Geology, Department of Geology, Institute of Geosciences, Universidade Federal da Bahia - UFBA, Salvador (BA), Brazil. E-mails: simonecruzufba@gmail.com; johildo.barbosa@gmail.com; lccgomes@gmail.com

2Department of Geology, Escola de Minas, Universidade Federal de Ouro Preto - UFOP, Ouro Preto (MG), Brazil. E-mail: ffalkmim@gmail.com ${ }^{3}$ Department of Regional Geology and Geotectonics, School of Geology, Universidade do Estado do Rio de Janeiro - UERJ, Rio de Janeiro (RJ), Brazil. E-mail:ivodusin@yahoo.com.br

${ }^{*}$ Corresponding author.

Manuscript ID: 30240. Received: 02/18/2015. Approved: 09/25/2015. 


\section{INTRODUCTION}

Most deformation imprinted on old continental blocks is accommodated with reactivation of pre-existing structures (Charrier et al. 2002, Butler et al. 2006, Cunningham 2005, 2013, among others). One of the clearest examples of tectonic reactivation is the nucleation of reverse fault from existing normal faults in continental margins, which is known as the process of positive tectonic inversion (Letouzey 1990). The inversion of deformational structures has been recognized in intracontinental domains (for example Ziegler 1983, Letouzey 1990, Charrier et al. 2002, Cunningham 2005, 2013), in active continental margins, and in collisional environments (Ziegler 1983, Butler et al. 2006, Dhahri $\&$ Boukadi 2010). This process is well recorded in sectors that undergo several superimposed subsidence pulses, in areas where compression has affected a stratigraphic pile deposited in an extensional environment or even in reverse shear zones that were reactivated as normal ones (negative inversion) (Allmendinger et al. 1983, Jolivet et al. 1991, Faccenna et al. 1995).

Aulacogens are failed rifts developed in internal portions of continents (Burke \& Whiteman 1973, Burke \& Dewey 1973, Dewey \& Burke 1974, Hoffman et al. 1974, Sengör et al. 1978). According to such authors, their infilling is marked by the presence of thick sequences of sedimentary rocks, which are often associated with volcanic rocks. Their lateral limits are marked by deep fault zones that control sedimentation. Due to their position near orogenic belts, a great number of aulacogens is partially inverted.

The Paramirim Aulacogen (Figs. 1 and 2), located in the center-eastern portion of the state of Bahia, in Brazil, corresponds to a succession of rifts that were developed between 1.7 and $0.65 \mathrm{Ma}$ (Pedrosa-Soares \& Alkmim 2011). During the Neoproterozoic, extensional structures were partially inverted. Moreover, the Paramirim Aulacogen zone of maximum positive inversion, denominated as Paramirim Corridor (Alkmim et al. 1993) (Figs. 1 and 2), presents a general NNW-SSE orientation. It is comprised of Chapada Diamantina Ocidental Fold Thrust Belt, eastwards, and Northern Espinhaço Setentrional Fold Thrust Belt, westwards. These belts signalize the evolution of an Intracontinental Orogen, similar to what was described by Cunningham $(2005,2013)$.

From a tectonic point of view, two sectors can be separated in the Paramirim Corridor: the northern and southern (Cruz \& Alkmim 2006), as seen in Figure 1. The northern sector includes the region of interaction between Paramirim Aulacogen and Rio Preto-Riacho do Pontal orogenic belt (Fig. 1), as well as the portion of the aulacogen in which the normal faults of the basement were spared from inversion processes (Danderfer Filho 2000). The southern sector (Figs. 1 and 2) comprises the region of the Paramirim Aulacogen that was inverted in response to the collisions of Brasília Orogen and the counter-clockwise rotation of São Francisco-Congo Plate, culminating in the structure of the confined AraçuaíWest Congo Orogen (Alkmim et al. 2006) and the Rio Pardo Salient (Cruz \& Alkmim 2006). According to these authors, in this sector, dextral transpressional shear zones were nucleated and these structures were responsible for juxtaposing the basement units over the Proterozoic cover units of the aulacogen.

The present study had the main objective of describing and interpreting the extensional structures that followed the compressional evolution of the Paramirim Corridor southern sector. The Paramirim Aulacogen represents an important natural laboratory in which the structures of its positive inversion are very well preserved, as well as those coeval with late extensional reactivations. Since it is located within the intracontinental domain of a confined orogen, the Araçuaí Orogen, this is placed in a peculiar tectonic context, making this study widely interesting to the international literature.

\section{MATERIALS AND METHODS}

The present research involved fieldwork, during which geological mapping was performed at scales of 1:1,000; $1: 25,000 ; 1: 50,000$ and 1:100,000. Moreover, descriptions of geological sections, microstructural analysis, and crystallographic fabric (quartz C-axis) and paleostress studies were carried out. Tectonite samples were collected from sites that are not illustrated in Fig. 2, but consisting in normal shear zones that either truncate or are parallel to Neoproterozoic compressional structures, especially tectonites generated by the deformation of Lagoa Real Intrusive Suite. This unit was chosen for the present study due to its Statherian age and because it presents only one deformation episode, which happened during the Ediacaran Period (Cruz \& Alkmim 2006). Microstructural and crystallographic fabric (C-axis) analyses were performed on the $\mathrm{XZ}$ plane of the finite strain ellipsoid of the normal shear zones. The quartz $\mathrm{C}$-axis was determined through a U-stage available at the Microanalysis Laboratory (Microlab) of the Universidade Federal de Ouro Preto.

The paleostress analysis was conducted on six outcrops located in abandoned quarries (Fig. 2). There are extensional shear zones that reactivate compressional inversion structures of the Paramirim Aulacogen outcrop in these sites. Data were gathered in these quarries regarding the shear plane, the mineral stretching lineation and movement indication, in this case, suggested by the presence of S/C structures and slickensides. The direction determination of the 
main stress tensor was performed through the Win-Tensor software developed by Delvaux (2012).

For the ${ }^{40} \mathrm{Ar} /{ }^{39} \mathrm{Ar}$ analyses, samples were irradiated with the GA-1550 standard (McDougall \& Harrison 1999) and then they were applied to the nuclear reactor of the Instituto de Pesquisas Energéticas (IPEN) of Universidade de São Paulo (USP), IPEN/CNEN IEA-R1, operating at 2 megawatts. Sample irradiation was performed in combination with an international standard (Fish Canyon - sanidine) to monitor the flow of neutrons, with a complementary control of

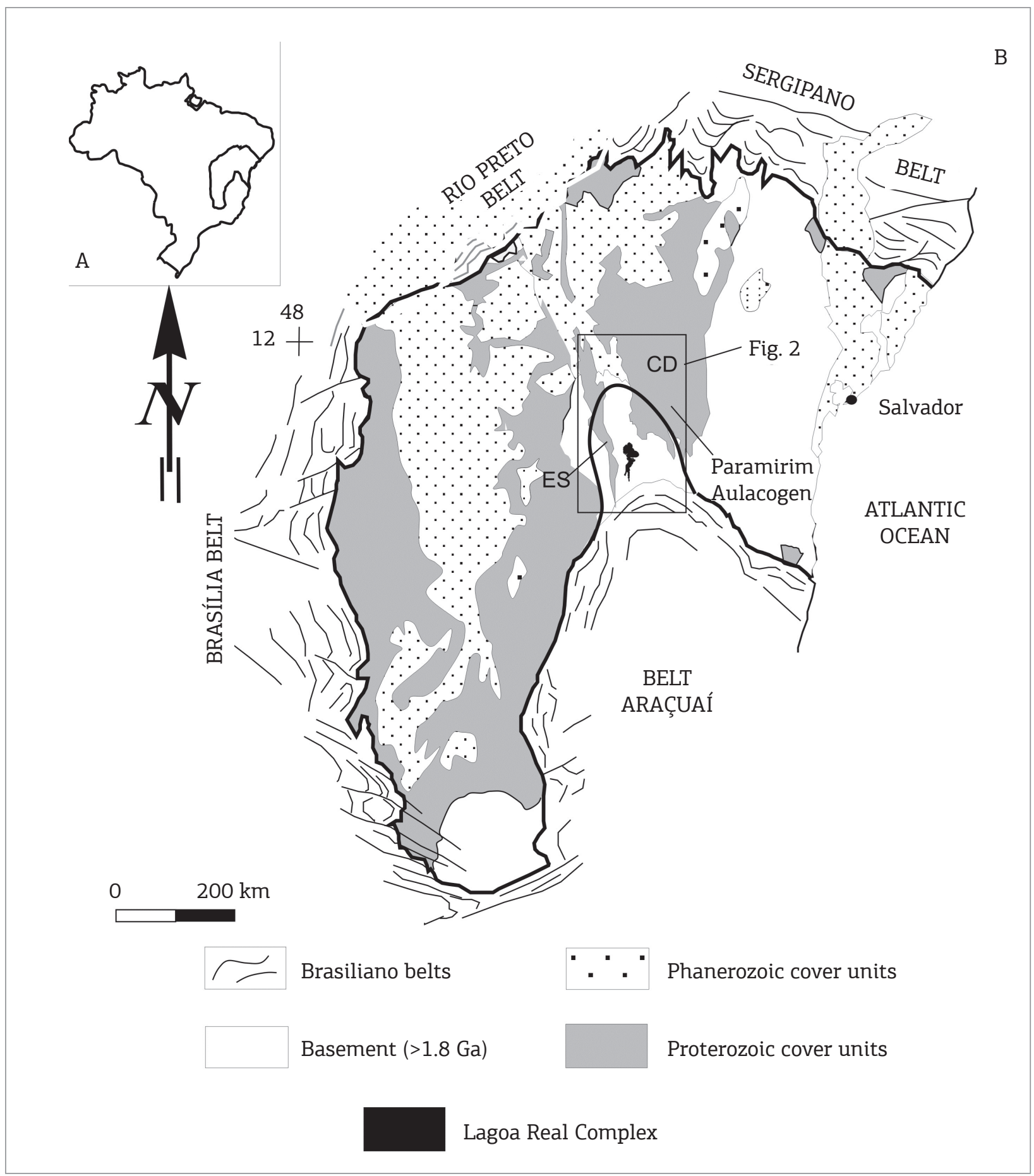

Figure 1. (A) Upper left inset locating the Sâo Francisco Craton at South American continent. (B) Simplified geological map of the São Francisco Craton showing the location of the Paramirim Aulacogen, Paramirim Corridor and Araçuaí Orogen (Modified from Alkmim et al. 1993). The rectangle indicates the position of Fig. 2. ES: Serra do Espinhaço Setentrional Fold Thrust Belt; CD: Chapada Diamantina Fold Thrust Belt. 
other international standards (GA-1550 - biotite, AC - sanidine, $\mathrm{Hb} 3 \mathrm{gr}$ - hornblende). The ${ }^{40} \mathrm{Ar} /{ }^{39} \mathrm{Ar}$ laboratory used a coherent argon laser source $(480-540 \eta \mathrm{m})$ with 6 watts of nominal power, Innova 90, for extraction by either step heating or total fusion of the irradiated samples. Measurements were taken through an argon extraction and purification

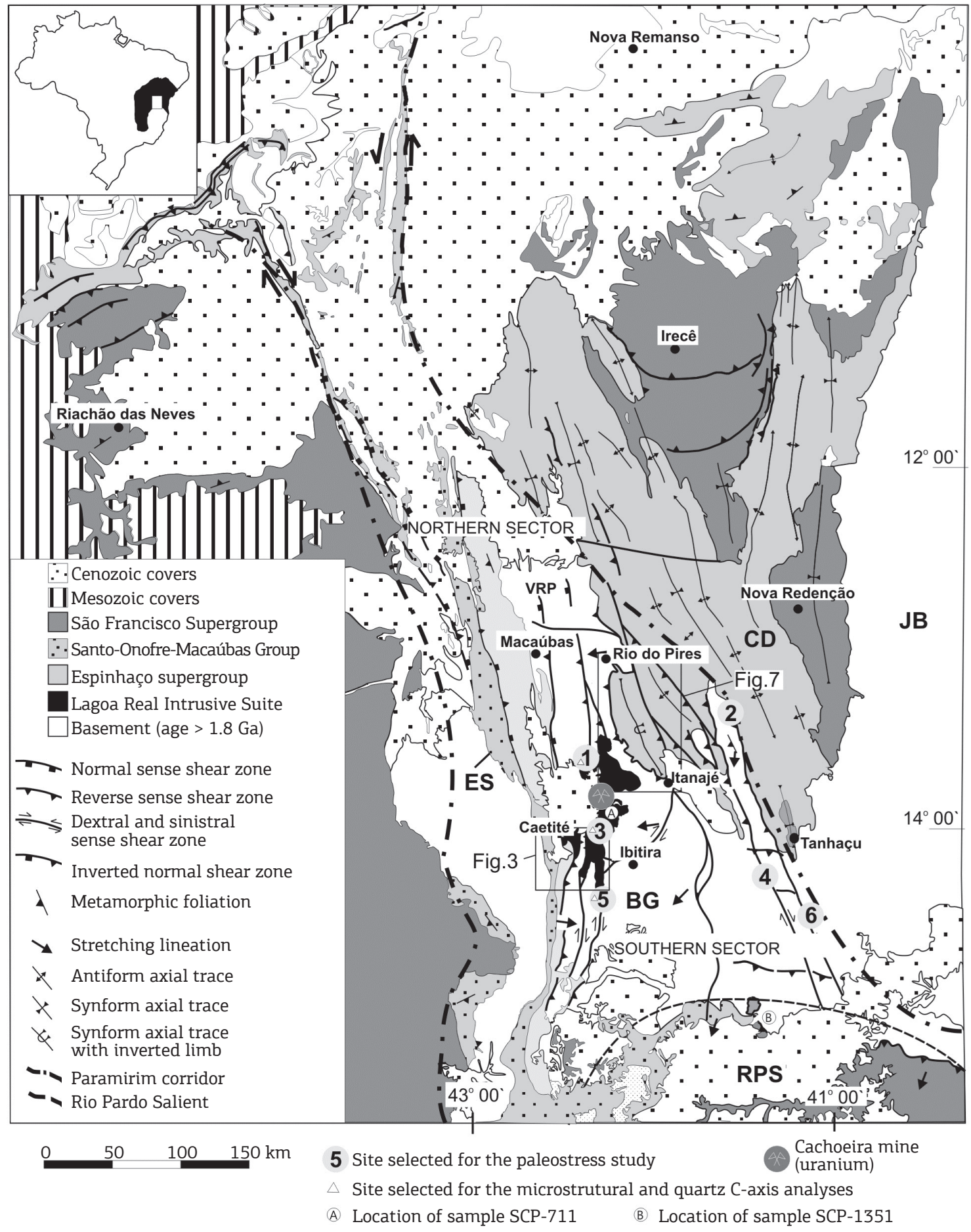

BG: Gavião Block, JB: jequié Block, ES: Northern Espinhaço Fold Thrust Belt, CD: Chapada Diamantina Fold Thrust Belt, RPO: Rio Preto Oregon, SRP: Rio Pardo Salient, VRP: Valley of the Paramirim Rivewr and SG: General range.

Figure 2. Simplified geological map of the Paramirim Aulacogen, emphasizing the main geological units and the tectonic structures of Ediacaran age (Cruz \& Alkmim 2006). Figures 3 and 7 are located herein. 
system with ultra-high-vacuum capacity connected to a high sensitivity mass spectrometer, MAP-215-50 Mass Analyser Products (England), as described in Vasconcelos et al. (2002).

\section{REGIONAL GEOLOGICAL CONTEXT}

The Paramirim Aulacogen (Pedrosa-Soares et al. 2001) is a large morphostructural feature located on the São Francisco-Congo Paleoplate that includes the Northern Serra do Espinhaço mountain range, Paramirim and São Francisco valleys, and Chapada Diamantina (Fig. 2).

Generated from a succession of rift/syneclise stages that took place between 1.75 and $0.67 \mathrm{Ma}$ (Pedrosa-Soares \& Alkmim 2011), the Paramirim Aulacogen experienced a pronounced inversion during the Ediacaran (Danderfer Filho 2000, Cruz \& Alkmim 2006, Guimarães et al. 2005, 2012, Cruz et al. 2012). The aulacogen substrate is composed of Archean granitoids, which were gneissified and migmatized, Paleoproterozoic metavolcanossedimentary sequences and Siderian, Rhyacian and Orosirian granitoids (Santos-Pinto et al. 1998, Bastos Leal et al. 1998, 2000).

The Lagoa Real Intrusive Suite represents the alkaline and anorogenic granitoids of this aulacogen (Teixeira 2000). This intrusive suite includes predominantly syenites, syenogranites and alkali-feldspar granites, which are leucocratic and mostly either porphyritic or medium phaneritic in their texture (Cruz et al. 2007b). The crystallization age of these rocks is around $1.7 \mathrm{Ga}$ (Turpin et al. 1988, Cordani et al. 1992, Cruz et al. 2007b).

The aulacogen infilling units are Espinhaço, São Francisco Supergroups and the Macaúbas-Santo Onofre Group (Fig. 2). The Espinhaço Supergroup is represented by a sequence of siliciclastic rocks with acid metavolcanic rocks, including the deposition age varying between 1.75 and $0.9 \mathrm{Ga}$ (Chemale-Júnior et al. 2012, Guadagnin et al. 2015). The São Francisco Group of Cryogenian age (Misi et al. 2011) comprises diamictites, quartz-sandstones, greywackes, arkoses and pelites on its base, which is covered of carbonate lithofacies (Guimarães et al. 2012). In turn, the Santo Onofre-Macaúbas Group, with maximum age of $0.9 \mathrm{Ga}$ (Babinsky et al. 2011), includes feldspar metasandstones and metaquartz sandstones, oligomictic metaconglomerates, phyllites and hematite metapelites, which are rich in graphite, manganese or sericites (Guimarães et al. 2012).

The rocks from Espinhaço Supergroup are cut by mafic and tholeiitic dikes and sills from the continental intraplate environment (Teixeira 2005, 2008, among others), with ages between $1.4-1.6$ and $0.8-0.9 \mathrm{Ga}$ (Guimarães et al. 2005, Danderfer Filho et al. 2009, among others).
The Paramirim Aulacogen presents the following four sets of deformation structures:

- structures that are exclusive to the aulacogen basement, which comprises gneissic banding, folds and gneissic domes observed especially in the Rhyacian-Orosirian units; - extensional structures that are associated with the aulacogen formation from the Statherian to the Tonian period, and were preserved to the north from parallel $12^{\circ} 45^{\prime}$ $S$ and south from parallel $12^{\circ} 15^{\prime} \mathrm{S}$. This set comprises normal-to-normal dextral shear zones that outcrop north from the municipality of Macaúbas (Fig. 2);

structures that reflect its positive inversion (Fig. 2), represented, in general, by reverse to transpressional shear zones and regional folds, distributed along the northern and southern sectors of the Paramirim Corridor (Fig. 2); and

- late extensional structures that reflect its negative inversion (Cruz \& Alkmim 2006), especially in its southern sector, and which are the subject of the present study.

The collection of available geochronological data for the Neoproterozoic shear zones of Paramirim Corridor (Fig. 2) are detailed in Table 1.

\section{COMPRESSIONAL DEFORMATION STRUCTURES ASSOCIATED WITH THE POSITIVE INVERSION OF PARAMIRIM AULACOGEN}

This group of structures has been extensively described by Danderfer Filho (2000), Lagoeiro (1990), Cruz and Alkmim (2006, 2007a), Guimarães et al. (2005, 2012), Cruz et al. (2007b, c, 2012) and Borge et al. (2015), among others. It reflects a regional stress field oriented WSW-ENE (Cruz \& Alkmim 2006). In the southern portion of the Aulacogen, two sets of older deformation structures were hierarchized by Cruz and Alkmim (2006) as $\mathrm{D}_{\mathrm{a}}$ and $\mathrm{D}_{\mathrm{p}}$, respectively. The $\mathrm{D}_{\mathrm{a}}$ structures are represented by schistosity (sensu Fettes \& Desmons 2007) and gneissic banding, which are parallel to each other and positioned at a low dipping angle, as well as by high rake stretching lineation and sheath folds that mark the Rio Pardo Salient (Cruz \& Alkmim 2006). Based on such investigators, these structures are developed predominantly in units of the Archean-Paleoproterozoic basement of the aulacogen, as well as in those of the Macaúbas Group.

The $\mathrm{D}_{\mathrm{p}}$ structures are related to the aulacogen frontal inversion (Cruz \& Alkmim 2006). This dominant set truncates $\mathrm{D}_{\mathrm{a}}$ structures and is associated with the generation of Paramirim Corridor (Alkmim et al. 1993). Southwards, entering the state of Minas Gerais, these structures get 
Table 1. Synthesis of the geochronological data available for the shear zones of Paramirim Corridor.

\begin{tabular}{|c|c|c|c|}
\hline \multirow{2}{*}{ Author } & \multicolumn{3}{|c|}{ Method } \\
\hline & $\mathrm{K}-\mathrm{Ar}$ & Ar-Ar & U-Pb (TIMS) \\
\hline Jardim de Sá et al. (1976) & $492 \pm 25 \mathrm{Ma}$ & & \\
\hline Pimentel et al. (1994) & & & $961 \pm 21 \mathrm{Ma}$ \\
\hline \multirow{2}{*}{ Cordani et al. (1992) } & & 491 to 514 (Anf) & \\
\hline & & 538 and $573(\mathrm{Bt})$ & \\
\hline Turpin et al. (1988) & & & $487 \pm 7 \mathrm{Ma}(\mathrm{Zr})$ \\
\hline \multirow{5}{*}{ Bastos Leal (1998) } & $507 \pm 6 \mathrm{Ma}(\mathrm{Bt})$ & & \\
\hline & $1064 \pm 12 \mathrm{Ma}(\mathrm{Bt})$ & & \\
\hline & $551 \pm 6 \mathrm{Ma}(\mathrm{Bt})$ & & \\
\hline & $490 \pm 12 \mathrm{Ma}(\mathrm{Bt})$ & & \\
\hline & $483 \pm 5(\mathrm{Bt})$ & & \\
\hline \multirow{3}{*}{ Guimarães et al. (2008) } & & $484 \pm 2$ to $487 \pm 2 \mathrm{Ma}(\mathrm{Sr})$ & \\
\hline & & $513 \pm 2$ to $515 \pm 2 \mathrm{Ma}(\mathrm{Sr})$ & \\
\hline & & $586 \pm 2 \mathrm{Ma}(\mathrm{Sr})$ & \\
\hline
\end{tabular}

Bt: biotite.

connected to the shear zones that were mapped by Silva (2010). They are present in the rocks of the aulacogen substrate, where they truncate deformation structures older than 1.8 Ga in Lagoa Real Intrusive Suite and in Proterozoic units (Cruz \& Alkmim 2006, 2007a, Cruz et al. 2007b,c, 2012). This deformation phase was responsible for nucleating the Espinhaço Setentrional and Chapada Diamantina Fold Thrust Belts.

In the basement rocks of Paramirim Aulacogen and in Lagoa Real Intrusive Suite, the $\mathrm{D}_{\mathrm{p}}$ structures are either reverse or reverse-dextral, ductile to ductile-brittle, shear zones (Figs. 2, 3, 4A, 5A-B, 6A-B, 7, 8A-B), with NNW/ SSE orientation (Fig. 9A), and also pop-up structures (Cruz 2004, Borge et al. 2015). The shear-sense indicators in these zones are S/C structures. Intrafolial isoclinal folds integrate the structural framework (Fig. 6B). Folds with asymmetrical and symmetrical enveloping are associated with such deformation phase in the metavolcanossedimentary sequences of the basement (Borge et al. 2015), as seen in Figures 6A and $6 \mathrm{C}$. Moreover, a prominent mylonitic foliation was formed in Lagoa Real Intrusive Suite, parallel to a gneissic banding (Fig. 5B).

Southwards from parallel $12^{\circ} 45^{\prime} \mathrm{S}$ (Fig. 2), the $\mathrm{D}_{\mathrm{p}}$ shear zones caused thrusting of Archean and Paleoproterozoic units over Proterozoic cover units. Examples are the occurrences of reverse shear zones of Chapada Diamantina Fold Thrust Belt between the municipalities of Rio do Pires and Itanajé (Figs. 2, 7, 8A-C), and the Espinhaço Setentrional Fold Thrust Belts in the region of the municipality of Caetité (Figs. 2, 4C). Sinistral wrench shear zones with high plunging angles and general E-W orientation form this framework.
In the region of Ibitira municipality, these shear zones were in charge of thrusting the Statherian rocks of Lagoa Real Intrusive Suite over the basement units of Paramirim Aulacogen (Figs. 5A-C), which are Archean-Paleoproterozoic.

In turn, the Proterozoic aulacogen cover units (Espinhaço and São Francisco Supergroups, in addition to Santo Onofre Group) absorbed the deformation through the development of regional folds (Fig. 8D), with general NNW-SSE orientation, open to closed enveloping surfaces, symmetrical or asymmetrical geometry, parasitic folds in S, Z, M or W, and a high dipping angle for the axial foliation plane (Danderfer Filho 2000, Cruz \& Alkmim 2006, Cruz et al. 2012). Inter and intra-strata shear zones, which are either reverse or thrusting, besides duplexes and imbricate fans preceded the formation of regional folds in Chapada Diamantina Fold Thrust Belt (Cruz \& Alkmim 2006, Cruz et al. 2007c). Stratigraphic inversions can be observed in the units of Espinhaço Supergroup that are outcropped on the western margin of Chapada Diamantina (Água Quente Synclinal, Cruz et al. 2007a,b,c) and on the eastern border of Northern Espinhaço (southwards from Caetité municipality).

In the Northern Espinhaço Fold Thrust Belt, the top structure is oriented WNW (Cruz \& Alkmim 2006) (Figs. 2, 5 to 7 ), while in the Chapada Diamantina Fold Thrust Belt (Figs. 2 to 4), the tectonic transport associated with the structures of the $\mathrm{D}_{\mathrm{p}}$ family is, in general, oriented towards ENE (Cruz 2004, Cruz et al. 2007c).

Figure 9A illustrates the general orientation of phase $\mathrm{D}_{\mathrm{p}}$ shear zones nucleated in the Lagoa Real Intrusive Suite and in the infilling units of Paramirim Aulacogen. Figure 9B shows the distribution of the stretching lineation identified 


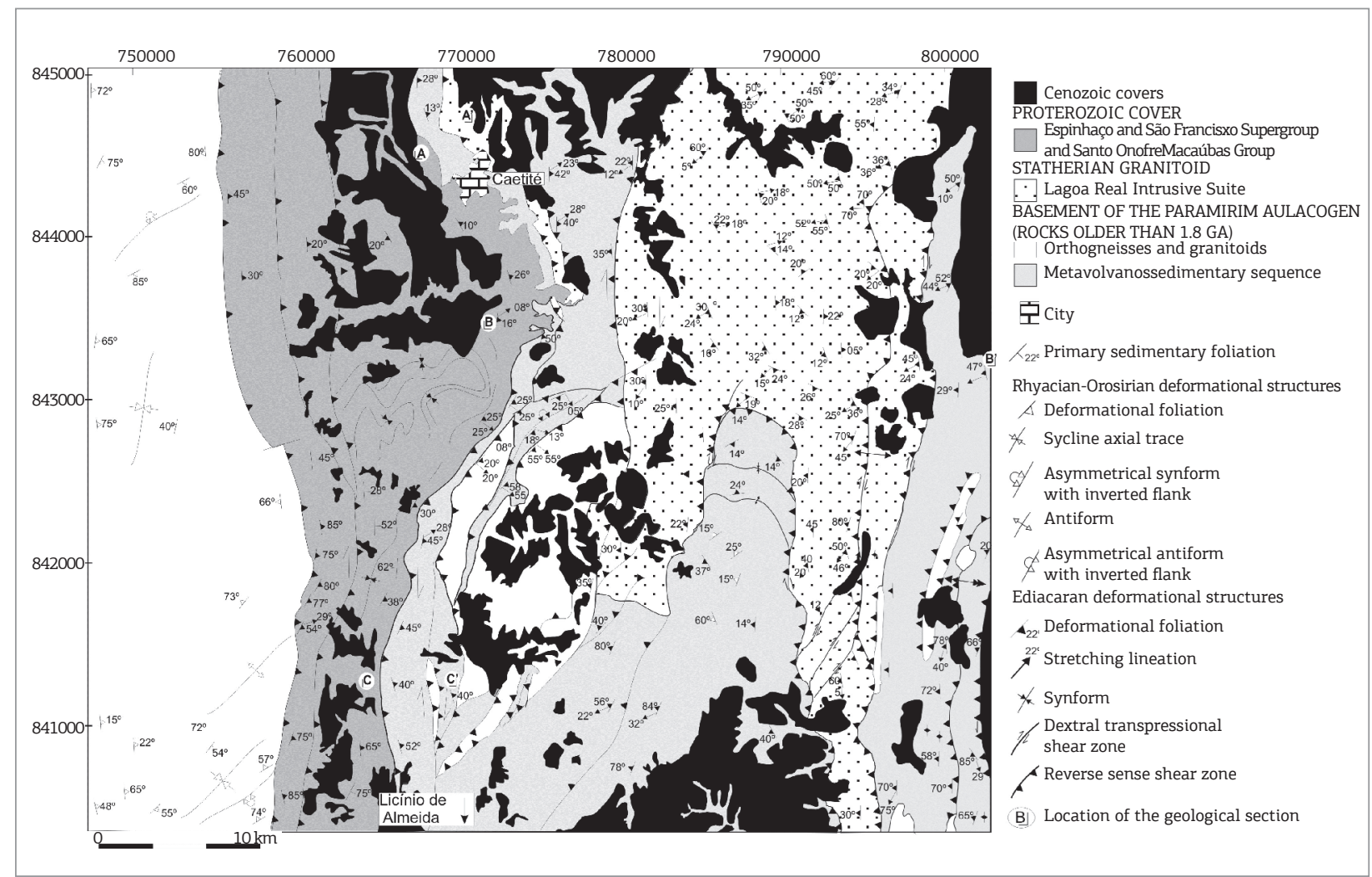

Figure 3. Geological map of the Northern Espinhaço Fold Thrust Belt southwards from the municipality of Caetité. Modified from Cruz et al. (2009). The profiles of Figs. 4 and 5 are positioned in the map. The location of the present figure is indicated in Fig. 2.

in these zones. Structures with high obliquity are predominant, although lineation with medium to low rake angles can be found, especially to the south of Caetité and Itanajé municipalities (Cruz \& Alkmim 2006).

The Irecê region (Fig. 2) comprises a set of folds and thrust faults with general E-W direction, formed through mass movements that occurred from north to south, which were originated from Riacho do Pontal Fold Thrust Belt (Lagoeiro 1990), and that follow the structure family of phase $D_{p}$.

\section{RECORD OF THE LATE EXTENSIONAL DEFORMATION OF PARAMIRIM AULACOGEN: RESULTS}

\section{Main macroscopic structures of phase $D_{e}$}

The characteristic elements regarding the $\mathrm{D}_{\mathrm{e}}$ deformation phase comprises: normal, planar or anastomotic shear zones (sensu Passchier \& Trouw 2005), with thickness varying between $1 \mathrm{~cm}$ and $1 \mathrm{~m}$ (Figs. 5D-E; 6D; 8E-F), which were identified in several outcrops in the area, but occur subordinately in relation to the compressional structures, making mapping difficult in a regional scale.; one foliation, at times mylonitic, and one down dip stretching lineation; asymmetrical, parasitic, inclined, reclined with plunge folds (sensu Fleuty 1964) (Figs. 4D, 5D, 10A) or recumbent ones, with the possibility of crenulation; traction fractures that are, in general, either vertical or in a high angle (Figs. 10B-C); and S/C structures (Fig. 8E).

In essence, the formation of $\mathrm{D}_{\mathrm{e}}$ structures occurred through extensional reactivation of $\mathrm{D}_{\mathrm{p}}$ structures, i.e. either through their negative inversion or by the development of normal shear zones that truncate the structures of phase $\mathrm{D}_{\mathrm{p}}$ (Figs. 4 to 6 and 8). In the first case, since the structures are the product of reactivation, it is common to observe reverse and normal movement domains in the same outcrop, which alternate longitudinally and transversally (Figs. 8E-F). In the second case, parasitic folds are seen (Figs. 5D-E).

Extensional $\mathrm{D}_{\mathrm{e}}$ structures can be observed in the gneissified rocks of Lagoa Real Intrusive Suite, which truncate the mylonitic and compressional, $\mathrm{D}_{\mathrm{p}}$, foliation of these rocks. For example, normal shear zones were found eastwards from this belt, in the region near the municipality of Caetité (Fig. 5D), as well as in Cachoeira Mine (Fig. 10A).

In the Northern Espinhaço Setentrional Fold Thrust Belt, eastwards from the municipality of Caetité (Fig. 2), 


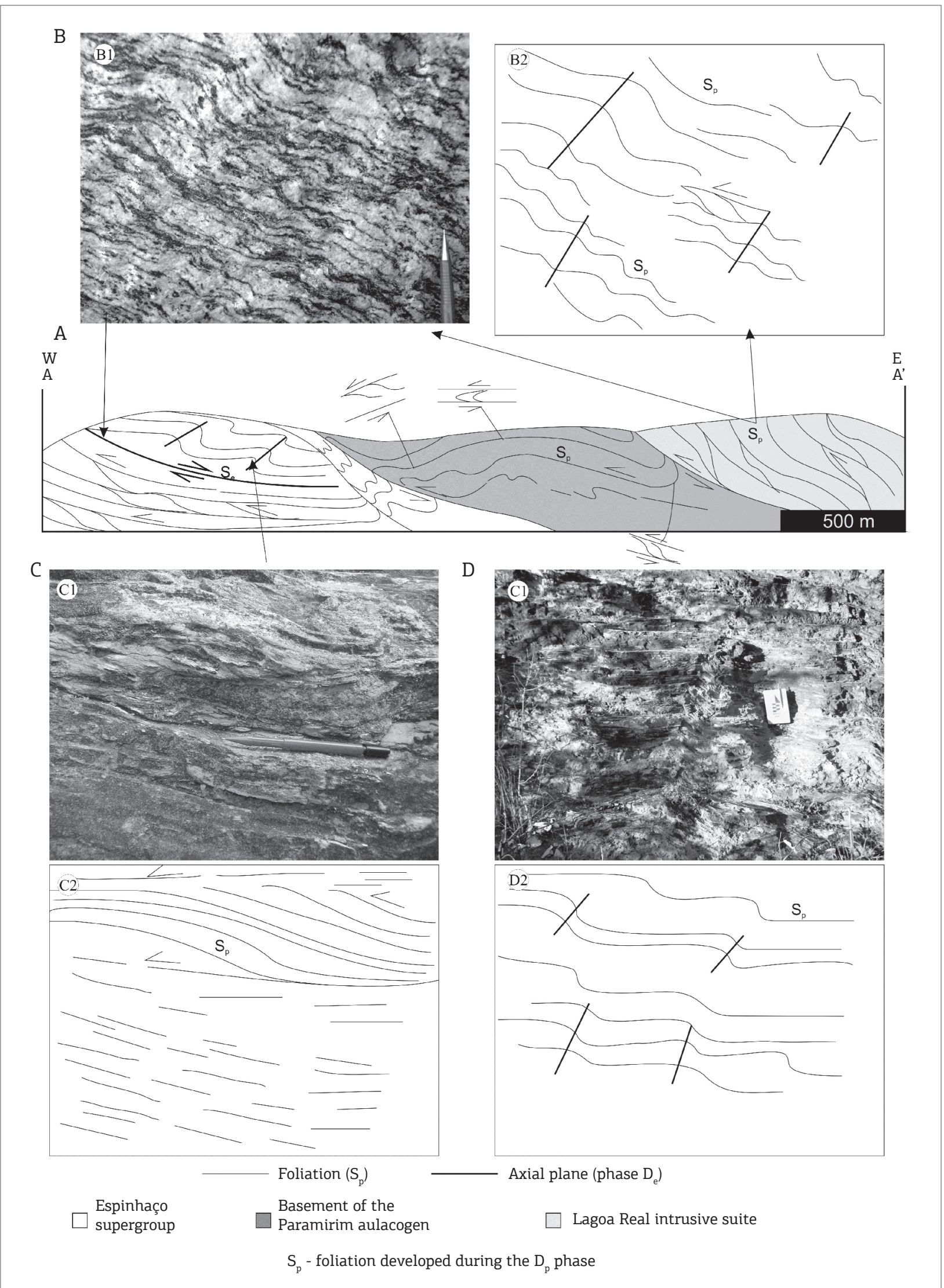

Figure 4. (A) Schematic profile of the structures of the Northern Espinhaço Fold Thrust Belt southwards from the municipality of Caetité. $(B, C)$ Structures of the $D_{p}$ phase present in the Lagoa Real Intrusive Suite and in the Espinhaço Supergroup, respectively. (D) Folds developed during $\mathrm{D}_{\mathrm{e}}$ in metasandstones of the Espinhaço Supergroup. 
the reverse shear zones of phase $\mathrm{D}_{\mathrm{p}}$ presented tectonic transport towards SW and were responsible for thrusting rocks of Lagoa Real Intrusive Suite over rocks from the basement of Paramirim Aulacogen, and then over the units of the Espinhaço Supergroup (Figs. 3 and 4A-B). Thus, a prominent deformation foliation is developed in metasandstones of Espinhaço Supergroup, while S/C structures suggest tectonic transport towards SW (Fig. 4B).

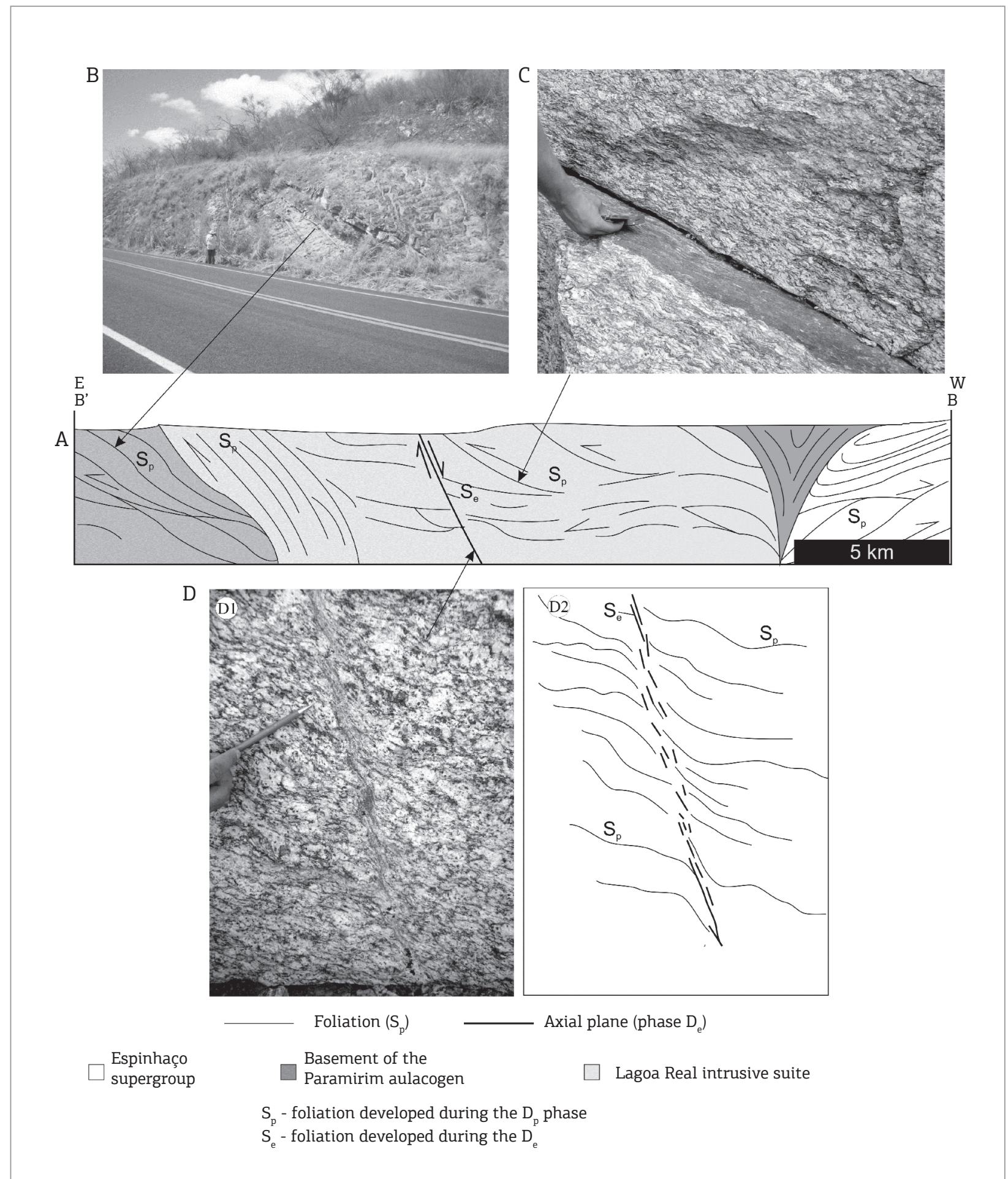

Figure 5. (A) Geological profile positioned eastwards from the municipality of Caetité (see location in Fig. 3). (B, C) Deformations of phase $\mathrm{D}_{\mathrm{p}}$ in the metavolcanossedimentary rocks of the basement of Paramirim Aulacogen and in the Lagoa Real Intrusive Suite, respectively. (D) Parasitic folds of phase $\mathrm{D}_{\mathrm{e}}$ developed in Lagoa Real Intrusive Suite. 
In this same outcrop, $\mathrm{D}_{\mathrm{e}}$ elements, such as asymmetrical kink shear folds, which are moderately inclined (sensu Fleuty 1964) and with vergence directed towards NE (Fig. 4C-D), fold the $S_{p}$ foliation. This is opposed to the structural top of phase $\mathrm{D}_{\mathrm{p}}$, which is directed towards SW. Folds and crenulation cleavage are observable in the axial plane of these folds. Still within this same belt, not only are the Espinhaço Supergroup units deformed by the $\mathrm{D}_{\mathrm{e}}$ structures, but they also present normal shear zones and recumbent chevron folds (sensu Fleuty 1964), and a negative flower

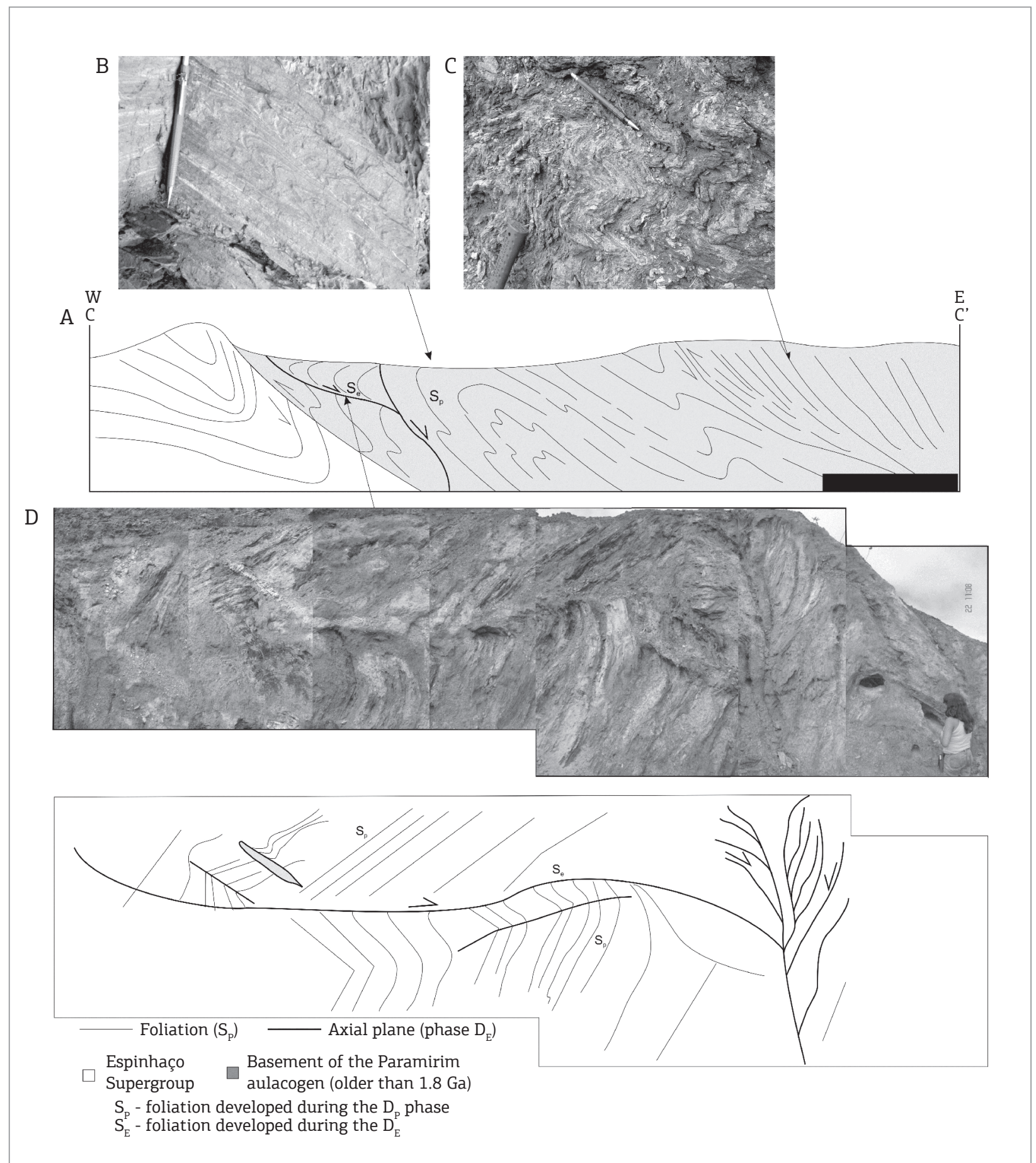

Figure 6. (A) Geological profile positioned southwards from the municipality of Caetité (see location in Fig. 3). $(B, C)$ Intrafolial isoclinal folds and folds from phase $D_{p}$ in the metavolcanossedimentary sequence of the basement of the Paramirim Aulacogen. (D) Normal shear zones and negative flower structure from phase $D_{e}$ in the metavolcanossedimentary sequence of the basement of Paramirim Aulacogen. 
structure in the basement units of the aulacogen (Fig. 6). These extensional structures truncate shear zones and folds from phase $\mathrm{D}_{\mathrm{p}}$, which were responsible for thrusting the basement units over Espinhaço Supergroup units.
In turn, along the profile between the municipalities of Paramirim and Érico Cardoso (Figs. 7 and 8), Chapada Diamantina Fold Thrust Belt shows extensional shear zones, which have their structural top directed towards SW, while the

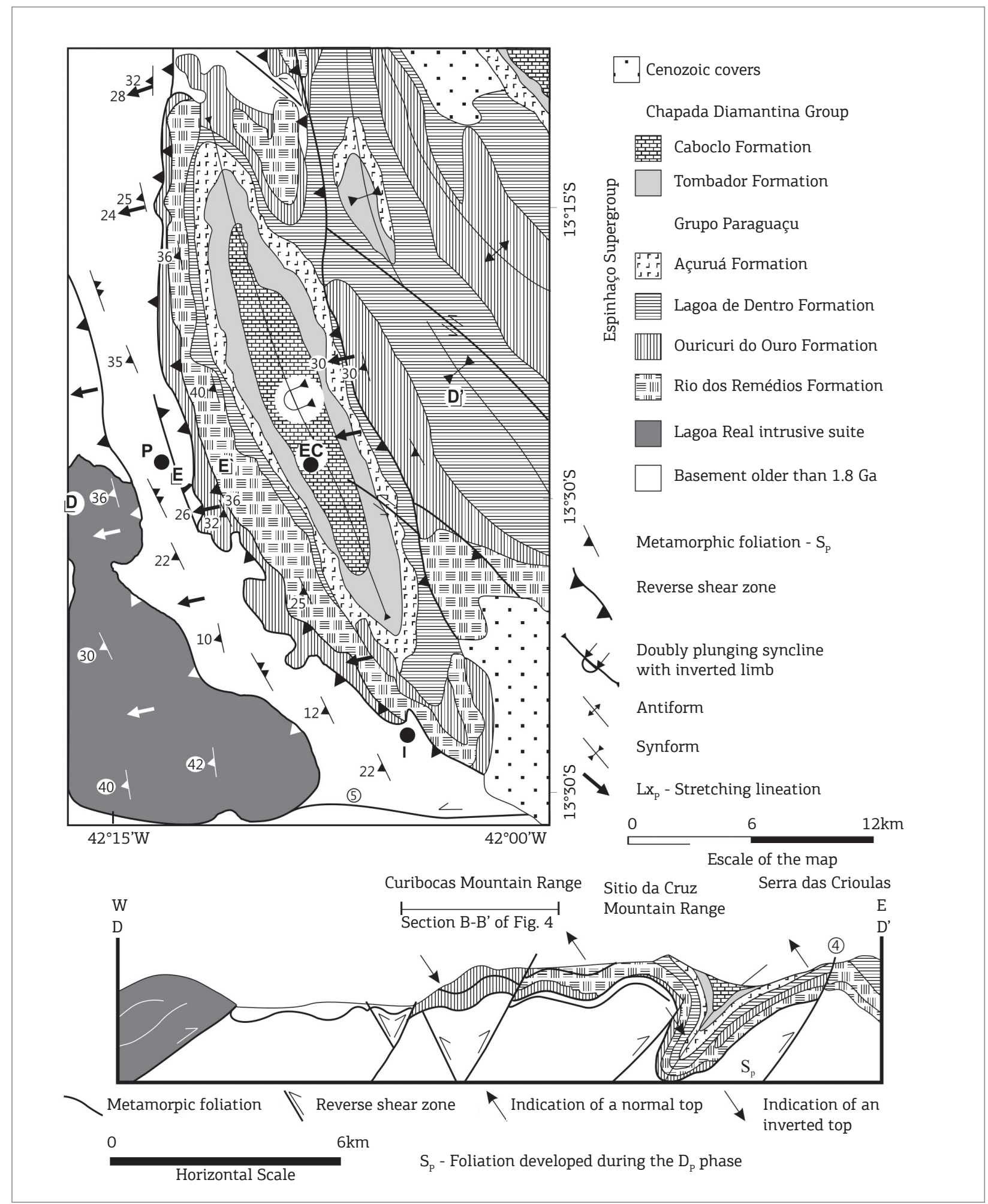

Figure 7. Schematic geological map and profile of the western margin of Chapada Diamantina Fold Thrust Belt in the Paramirim region. Note the position of profiles D-D' and E-E'. Modified from Cruz et al. (2007c). 
tectonic transport associated with the compressional structures of phase $\mathrm{D}_{\mathrm{p}}$ is towards NE. Moreover, non-coaxial refolding features generating recumbent folds are also seen (Fig. 8F).
Quartz veins are found in normal shear zones and, in general, are oriented with a high dipping angle (Figs. 10B-C and 11).
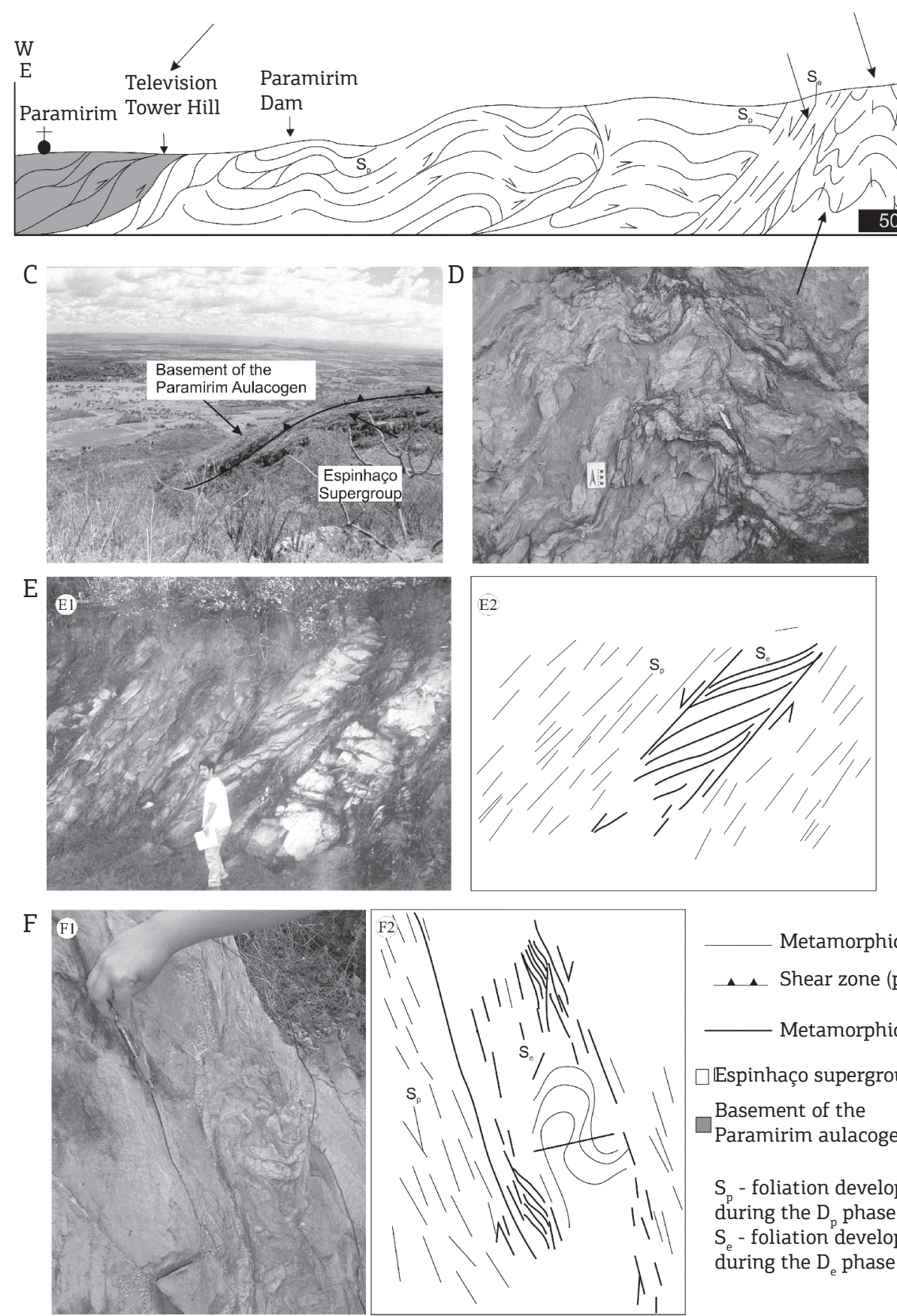

Metamorphic foliation ( $\left.\mathrm{S}_{\mathrm{p}}\right)$

„. Shear zone (phase $\mathrm{D}_{\mathrm{p}}$ )

Metamorphic foliation $\left(\mathrm{S}_{\mathrm{e}}\right)$

$\square$ Espinhaço supergroup

Basement of the

Paramirim aulacogen

$S_{p}$ - foliation developed during the $\mathrm{D}_{\mathrm{p}}$ phase $\mathrm{S}_{\mathrm{e}}$ - foliation developed during the $\mathrm{D}_{\mathrm{e}}$ phase

Figure 8. (A) Schematic geological profile of the region between Paramirim and Érico Cardoso municipalitiesshowing structures of the Dp phase. (B) Imbricate fans of phase Dp in basement rocks of the Paramirim Aulacogen. (C) Panoramic photo of the shear zone that thrusts the basement units of Paramirim Aulacogen over the rocks of Espinhaço Supergroup. (D) Folds from phase Dp in the rocks of Espinhaço Supergroup. (E) S/C structure in an extensional shear zone developed in the rocks of Espinhaço Supergroup. (F) Refolding developed during De in the rocks of Espinhaço Supergroup. 
Cutting and superposition relationships between $\mathrm{D}_{\mathrm{p}}$ and $\mathrm{D}_{\mathrm{e}}$ structures are frequently observed and very clear. Undoubtedly, $\mathrm{D}_{\mathrm{e}}$ elements affect the characteristic elements of phase $\mathrm{D}_{\mathrm{p}}$ in all situations.

\section{Microstructural analysis and quartz $\mathrm{C}$-axis fabric analysis}

In the $\mathrm{D}_{\mathrm{e}}$ shear zones, quartz, which is the main component of supracrustal units and is also present in the Lagoa
Real Intrusive Suite, accommodates deformation in a plastic deformational process, developing undulatory extinction and deformation bands, besides forming subgrains. By outlining porphyroclasts of this mineral, new polygonal grains can be found. This suggests the action of a recrystallization mechanism by means of subgrain rotation (sensu Poirier \& Guillopé 1979). However, the main deformation mechanism among the metasandstones and felsic metavolcanic

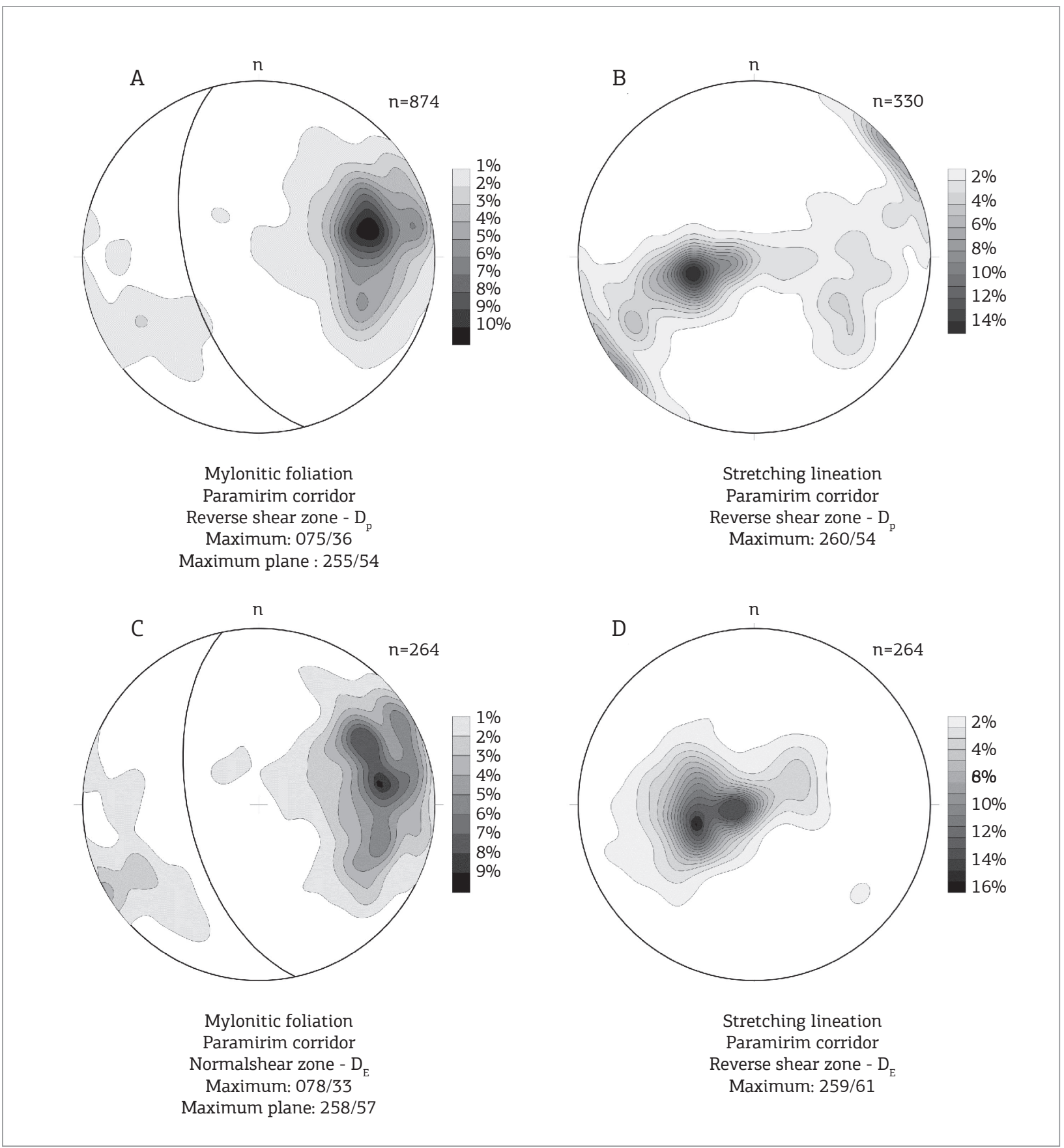

Figure 9. Synoptic stereographic diagrams (lower hemisphere) of the mylonitic foliation poles (A, C) and stretching lineation $(B, D)$ of the shear zones of Paramirim Corridor. Values calculated for $1 \%$ of the circle area. 
rocks of Espinhaço Supergroup is associated with pressure solution, considering the presence of grains that have been truncated at an angle through the foliation connected to the extensional shear zones (Fig. 12A).

K-feldspar is intensely fractured when found in the felsic metavolcanic rocks of Espinhaço Supergroup and in the tectonites of Lagoa Real Intrusive Suite, which were truncated by shear zones of phase $\mathrm{D}_{\mathrm{e}}$. Some domains also present intense transformation of K-feldspar and amphibolite into white mica (Fig. 12B) and chlorite, respectively, resulting in the formation of phyllonites. The intensity of hydrothermal alteration is variable and, in the domains of greater alteration, foliation is developed with variable anastomotic, discontinuous, planar or continuous characteristics (sensu Passchier \& Trouw 2005). The metamorphic mineralogical assemblage associated with the extensional shear zones is formed by epidote, muscovite, chlorite, quartz, and calcite.

Tectonite samples generated by granitoid deformation in Lagoa Real Intrusive Suite and located in the normal shear zones of phase $\mathrm{D}_{\mathrm{e}}$ showed a quartz $\mathrm{C}$-axis crystallographic fabric positioned at a high angle with the $S_{e}$ foliation (Fig. 13). The distribution of the maximum values demonstrated that the maximum was at $14^{\circ}$ from the $\mathrm{Z}$-axis, thus suggesting that deformation mainly activated the basal glide planes in the $<\mathrm{a}>$ direction.

\section{Dynamic meaning of $\mathrm{D}_{\mathrm{e}}$ structures}

The analysis carried out considering only normal shear zones and faults with small displacement revealed that the active regimen during the $\mathrm{D}_{\mathrm{e}}$ phase varied between radial and

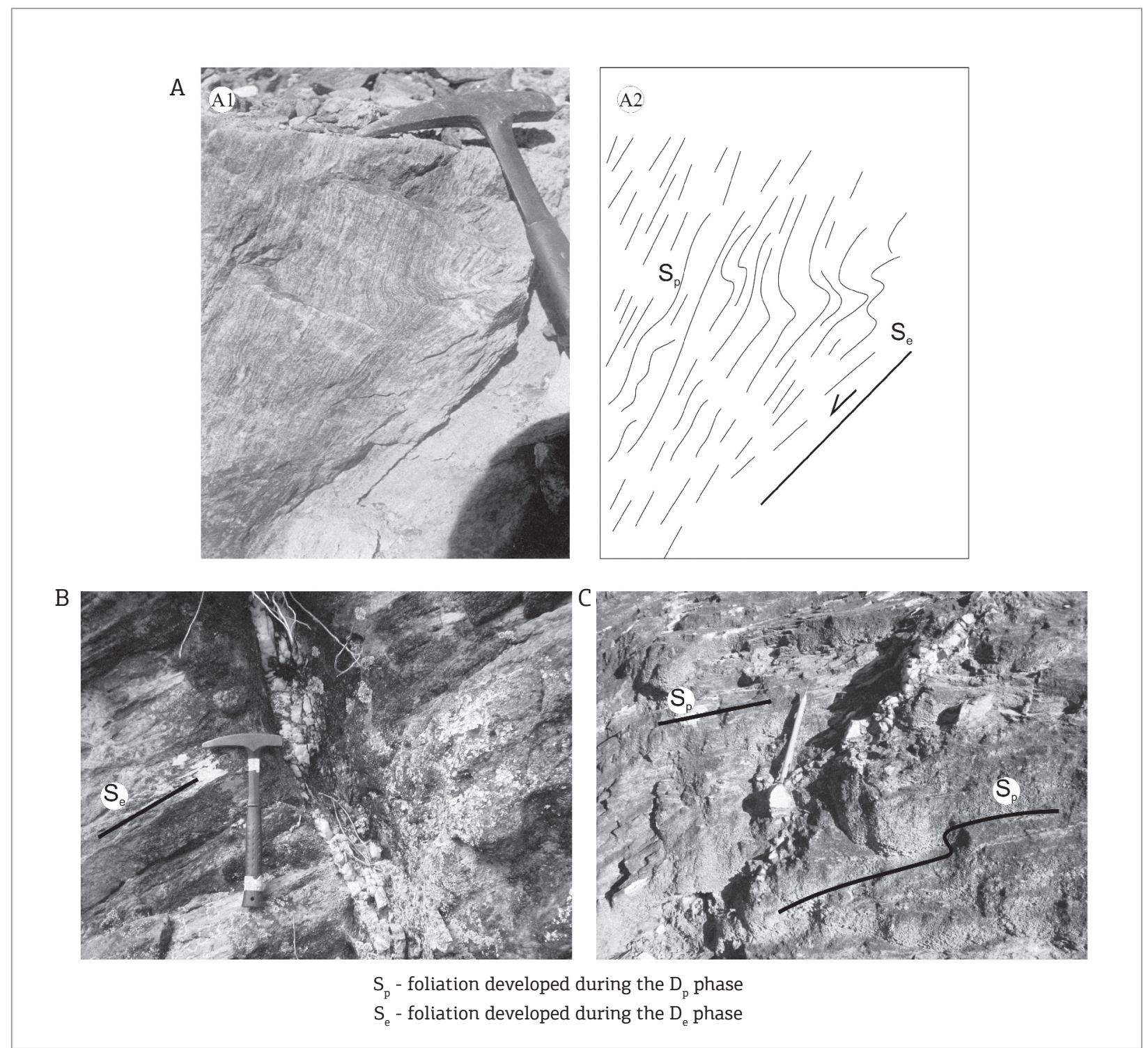

Figure 10. (A) Folds from phase $\mathrm{D}_{\mathrm{e}}$ in the rocks of Lagoa Real suite; $(\mathrm{B}, \mathrm{C})$ Quartz veins in normal shear zones. 
pure extensions (Fig. 14). The direction of $s_{1}$ oscillated near the vertical position, while $s_{3}$ was sub-horizontally, though N230- $050^{\circ}$ was the predominating direction (Tab. 2).

Tensile fractures filled by either quartz or calcite may also be used as important indicators for the tectonic history of a region, as suggested by Durney and Ramsay (1973), Beutner and Diegel (1985), and Etchecopar and Malavieille (1987). In their interior, mineral fibers indicate the opening trajectory of the fractures that, in turn, is related to the position of the finite strain ellipsoid. As shown in the diagram of Fig. 13, the preferential direction of the veins in the $\mathrm{D}_{\mathrm{e}}$ shear zones occurs as NW-SE. More subordinately, NE-SW orientation is also observed among some veins. This radial distribution is compatible with the obtained regimens.

\section{${ }^{39} \mathrm{Ar} /{ }^{40} \mathrm{Ar}$ Analysis}

In both analyzed samples (SCP 711 and SCP 1351), biotite presented pleochroism, varying from brown to greenish-brown and was lamellar and subidioblastic, with granulation between 0.02 and $0.08 \mathrm{~mm}$. Undulating extinction was strong to moderate.

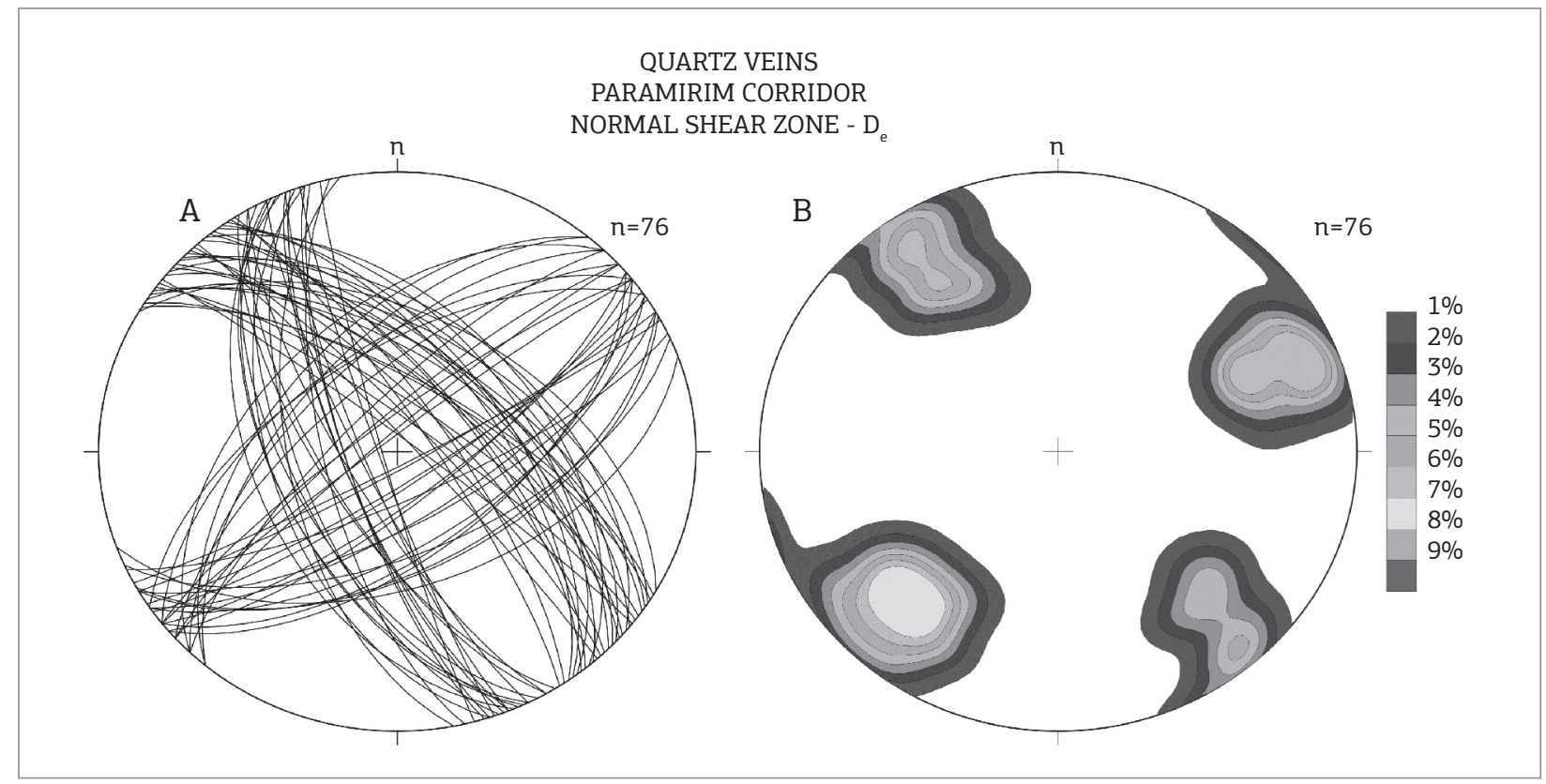

Figure 11. Stereographic diagrams of planes (A) and polar isodensity of quartz veins (B) lodged in extensional shear zones within the Paramirim Corridor. Lower hemisphere. The contour intervals are equal to 1, 2, 3, 4 and $5 \%$ by $1 \%$ of area.
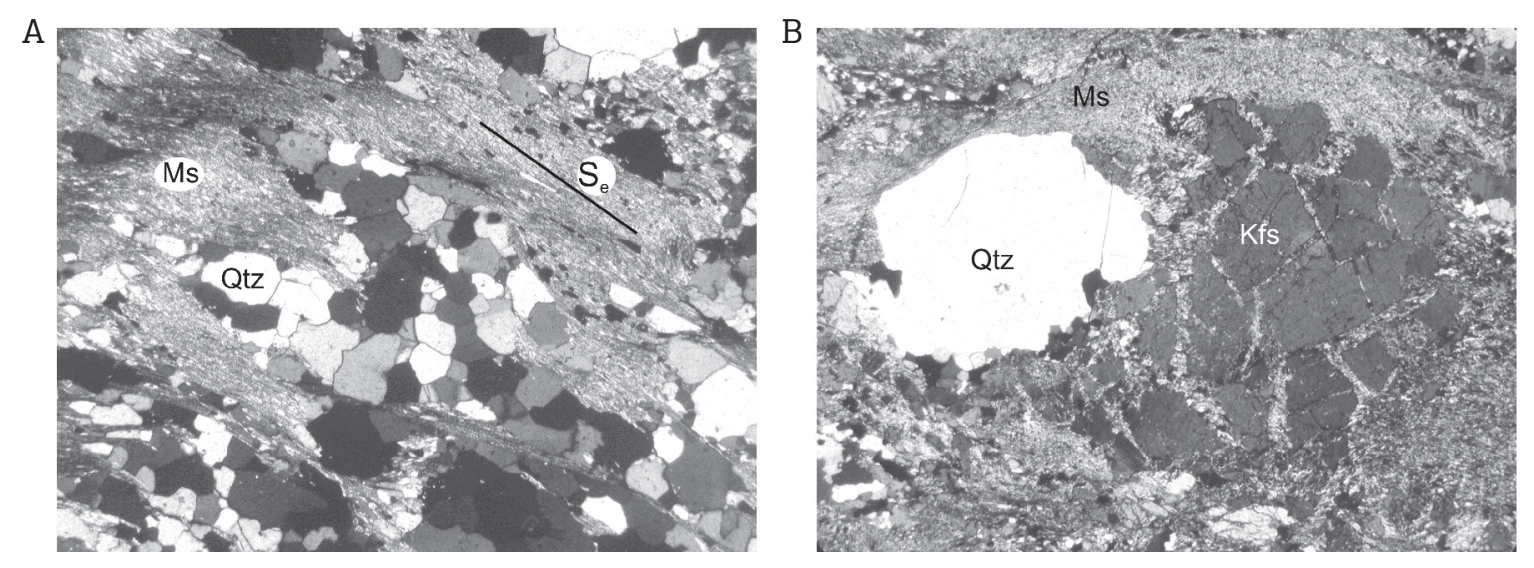

Figure 12. Deformational fabric in extensional shear zones. (A) Quartz (Qtz) aggregates truncated by $\mathrm{S}_{\mathrm{e}}$ foliation, which is rich in muscovite (Ms), in a metavolcanic rock of Espinhaço Supergroup. (B) K-feldspar (Kfs) grain that was fractured and altered to muscovite in a rock of Lagoa Real Intrusive Suite. 


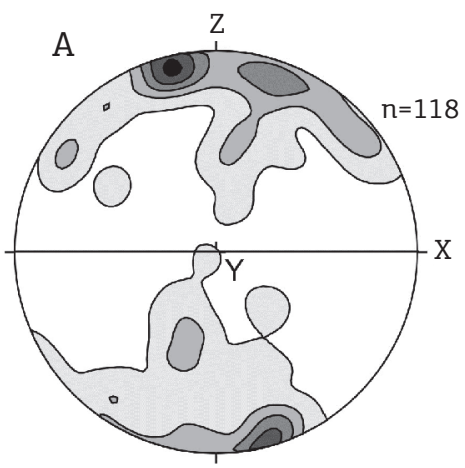

C-axis of quartz

Lagoa real intrusive suite

Normal shear zone

Maximum: 346/06

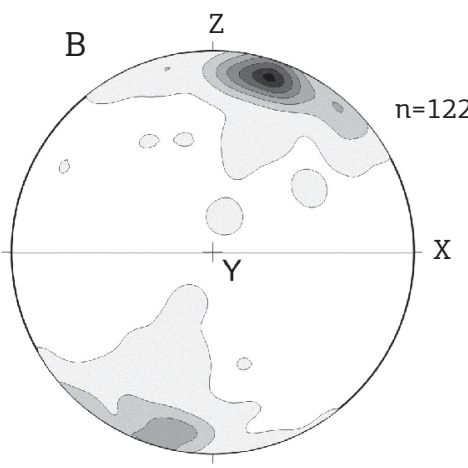

C-axis of quartz

Lagoa real intrusive suite

Normal shear zone

Maximum: 017/11

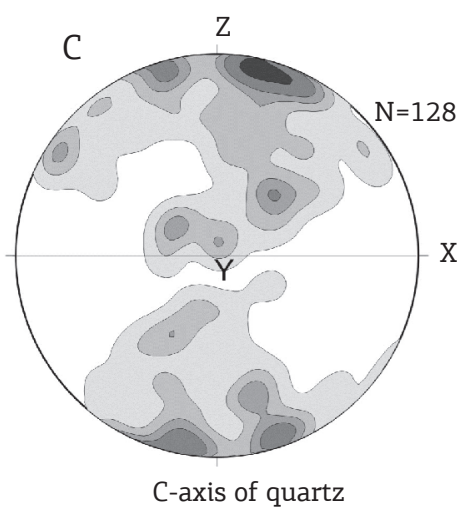

Lagoa real intrusive suite

Normal shear zone Maximum: 013/08

Figure 13. Stereographic diagrams of the $C$-axis quartz determined from tectonites of $D$ normal shear zones from the Lagoa Real Intrusive Suite. $\mathrm{X}$ and $\mathrm{Z}$ correspond to the axes of the finite strain ellipsoid. The contour intervals are equal to $1,2,3,4$ and $5 \%$ by $1 \%$ of area. In all diagrams, metamorphic foliation is parallel to the XY plane.
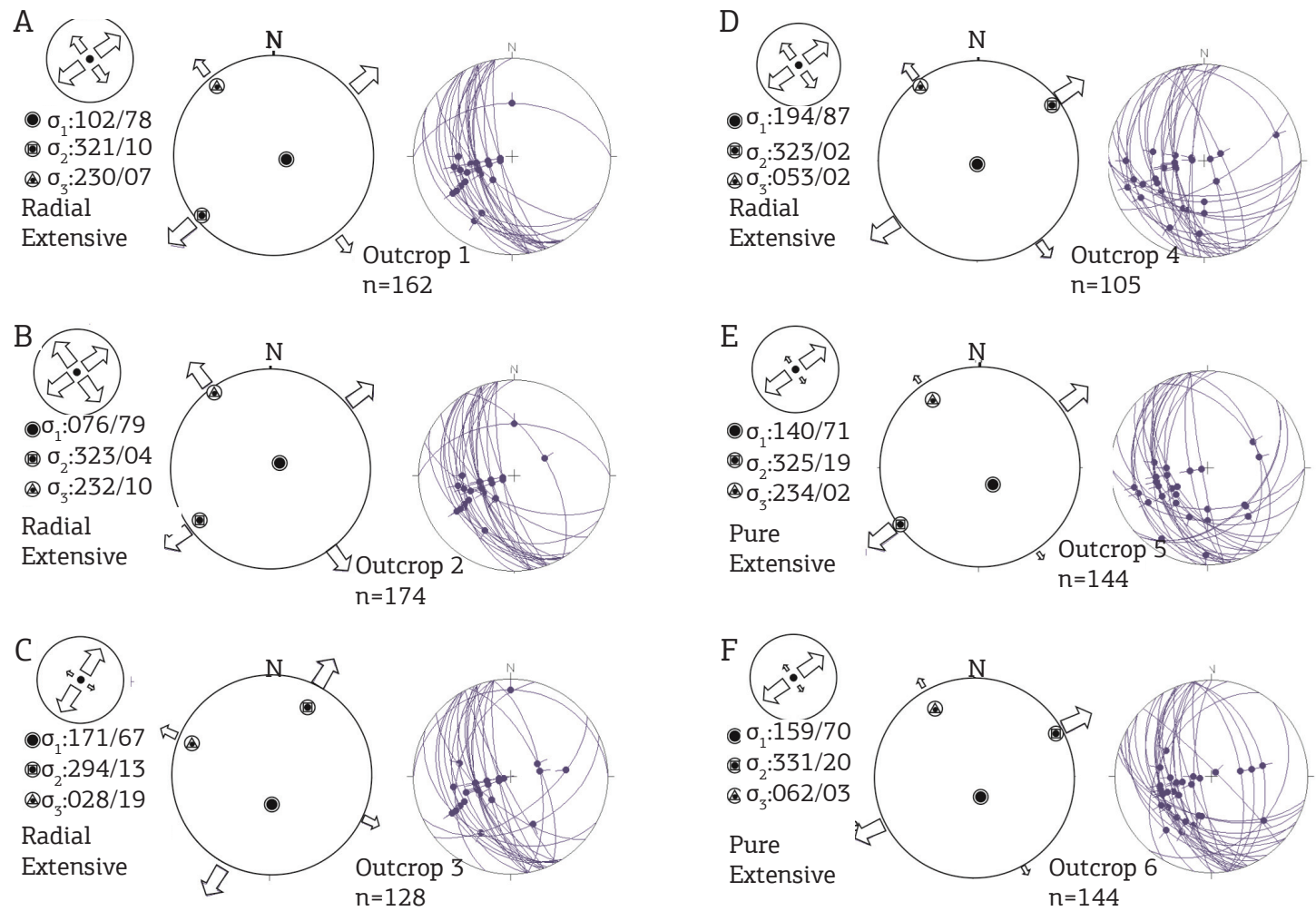

Figure 14. Paleostress direction diagram using data obtained from the sites presented in Fig. 2 and using the WinTensor software (Devaulx 2012). 
Results obtained for the grains of biotite in samples SCP 711 and SCP 1351 are expressed in the ${ }^{39} \mathrm{Ar} /{ }^{40} \mathrm{Ar}$ diagrams. These indicate a weighed age for concordant individual errors within the experimental errors (1 SD), using five step-heating processes (B; C; D; E and F) and then six step-heating processes (B; C; D; E; F and G), respectively (Figs. 15A-B; 16A). The plateau ages obtained for sample SCP 711 were $489.4 \pm 2.0$ and $492.3 \pm 1.5 \mathrm{Ma}$ (Figs. 15A-B, respectively), while it was $484.1 \pm 1.3 \mathrm{Ma}$ (Fig. 16A) for sample SCP 1351. Still considering sample SCP 1351, but for the five step-heating processes (B; C; D; E and F), the plateau age was determined as $485.7 \pm 1.2 \mathrm{Ma}$ (Fig. 16B).

The softened histogram for age versus probability of the two extracted grains offers the possible age of system opening. The diagrams built from the analyses performed describe well defined plateaus, which indicate a probable mean age of $491 \pm 2 \mathrm{Ma}$ for sample SCP 711 and $484.9 \pm$ 1.9 Ma for SCP 1351 (Figs. 15C and 16C). Coherently, the weighed means (Figs. 15D and 16D) offer a probable age of $491.3 \pm 7.0 \mathrm{Ma}$ for sample SCP 711 and $484.9 \pm$ 5.9 Ma for SCP 1351. Tables 3 and 4 present the analytical geochronological data obtained from $\mathrm{Ar}-\mathrm{Ar}$ for samples SCP-711 and SCP 1351, respectively.

\section{DISCUSSION}

The Paramirim Aulacogen has an evolution history of complex deformation, with the development of successive phases associated with its formation (Danderfer Filho 2000, Guimarães et al. 2012) and inversion (Cruz \& Alkmim 2006, 2007a; Cruz et al. 2007b,c). Southwards from parallel $12^{\circ} 45^{\prime} \mathrm{S}$, in Lagoa Real Intrusive Suite and in Espinhaço Setentrional and Chapada Diamantina Fold Thrust Belts, compressional deformation structures predominate associated with a stress field oriented WSW-ENE. The collisions of the Brasília Orogen would have led to the counter-clockwise rotation of São Francisco-Congo plate, forming the Araçuaí-West Congo Collisional Orogen (Alkmim et al. 2006). The northern extremity of Paramirim Aulacogen presents reactivation and inversion evidence of its extensional structures and of a mountain range construction within the intracontinental domain (sensu Cunningham 2005, 2013) of Araçuaí-West Congo Orogen, which is represented through Espinhaço Setentrional and Chapada Diamantina Fold Thrust Belts in the Paramirim Corridor. This mountain range was most likely formed as the result of a reflex effect related to a regional shortening due to the formation of Western Gondwana (Cruz \& Alkmim 2006).

In Araçuaí-West Congo Orogen, the greatest thickening of the crust is believed to have occurred in the southernmost sectors, leading to the development of intense syn- to tardi-collisional anatexis between 590 and $530 \mathrm{Ma}$ (PedrosaSoares et al. 2011), followed by post ones between 530 and $480 \mathrm{Ma}$. This late granite genesis seems to be associated with post-orogenic gravitational collapse. Marshak et al. (2006) described the structural collection regarding the late extension of this orogen. The set of structures presented in this study, and synthesized in Figure 17, either truncates or reactivates compressional deformation structures in the Paramirim Corridor that were formed during the construction phase of Araçuaí-West Congo Orogen. A strong structural control of the $\mathrm{D}_{\mathrm{p}}$ compressional structures over the $\mathrm{D}_{\mathrm{e}}$ extensional ones can be observed in the comparison of modal distribution of these structures.

In the northern portion of Araçuaí Orogen, specifically in the interaction zone with the Paramirim Aulacogen, there are no reports on the existence of granitoids associated with orogenic collapse. However, the truncation relations observed in the field suggest that these structures are of the same generation as those associated with the late extension of the orogen presented by Marshak et al. (2006).

Table 2. Synthesis of the results obtained in the paleostress study using the Win-Tensor software and data gathered in ornamented shear fractures.

\begin{tabular}{|c|c|c|c|c|c|c|}
\hline Station & 1 & 2 & 3 & 4 & 5 & 6 \\
\hline Coordinate & $\begin{array}{c}23 \text { L 780009/ } \\
8499031\end{array}$ & $\begin{array}{c}24 \text { L 221668/ } \\
8509740\end{array}$ & $\begin{array}{c}23 \text { L 792842/ } \\
8475607\end{array}$ & $\begin{array}{c}24 \text { L 233149/ } \\
8434285\end{array}$ & $\begin{array}{c}23 \text { L 791509/ } \\
8431824\end{array}$ & $\begin{array}{c}24 \text { L } 270220 \\
8412196\end{array}$ \\
\hline$\sigma_{1}$ & $102 / 78$ & 076/79 & $171 / 67$ & $194 / 87$ & $140 / 71$ & $159 / 70$ \\
\hline$\sigma_{2}$ & $321 / 10$ & $323 / 04$ & $294 / 13$ & $323 / 02$ & $325 / 18$ & $331 / 20$ \\
\hline$\sigma_{3}$ & $230 / 07$ & $233 / 07$ & 025/05 & 053/01 & $233 / 05$ & $062 / 03$ \\
\hline $\mathrm{R}$ & 0.21 & 0.03 & 0.24 & 0.17 & 0.37 & 0.34 \\
\hline Regime & $\begin{array}{l}\text { Radial } \\
\text { extension }\end{array}$ & $\begin{array}{l}\text { Radial } \\
\text { extension }\end{array}$ & $\begin{array}{l}\text { Radial } \\
\text { extension }\end{array}$ & $\begin{array}{l}\text { Radial } \\
\text { extension }\end{array}$ & $\begin{array}{c}\text { Pure } \\
\text { extension }\end{array}$ & $\begin{array}{c}\text { Pure } \\
\text { extension }\end{array}$ \\
\hline
\end{tabular}




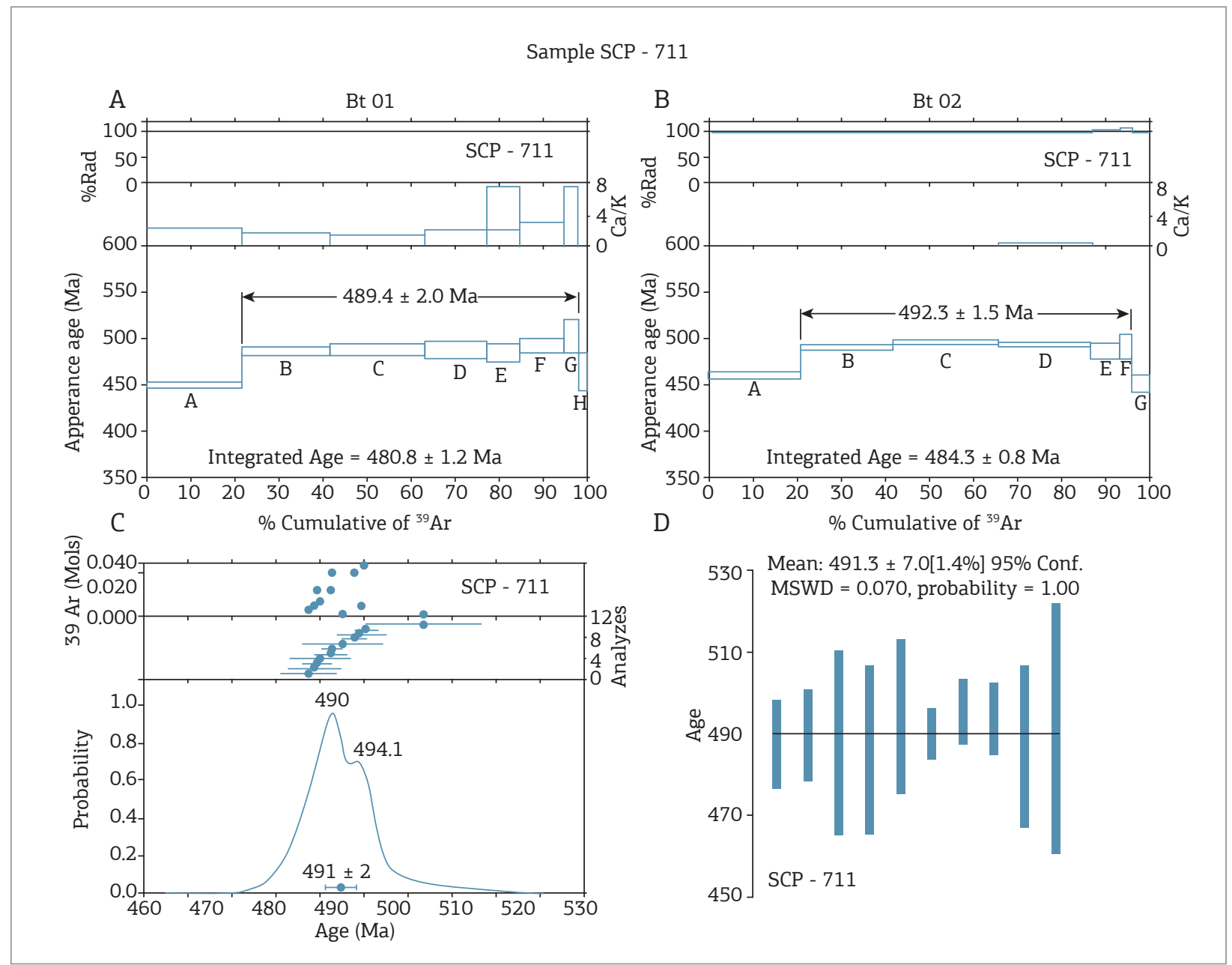

Figure 15. Results of the Ar-Ar analyses for sample SCP-711.

The regimen acting during phase $\mathrm{D}_{\mathrm{e}}$ varied between radial extension and pure extensions. In the site where a pure extension regimen was seen, the extension orientation was the same as that interpreted by Alkmim et al. (2006) and Cruz and Alkmim (2006) for the regional shortening, but in the opposite direction.

Negative inversion of compressional structures has been documented in several orogenic domains (Rey et al. 2001, Vanderhaeghe \& Teyssier 2001, Israel et al. 2013, Wang et al. 2014, among others). In many situations, they have been attributed to the gravitational collapse that affects systems in more advanced phases of their evolution. In orogenic domains, one of the main factors that contributes to collapse is the lateral variation in the accumulation of potential gravitational energy (Rey et al. 2001, among others). The effects associated with this extension varied since the development of faults, in brittle-to-brittle ductile conditions, until the development of partial fusions and metamorphic core complexes, in ductile conditions (Vanderhaeghe \& Teyssier 2001). The microstructural analysis conducted in the late extensional shear zones of Paramirim Corridor revealed that, at a microscale, ductile deformation features predominated in quartz, while brittle fracturing in K-feldspar. The quartz C-axes distribution happens predominantly according to the Z-axis of the finite strain ellipsoid, suggesting the activation of basal planes. Based on the studies by Simpson (1986), FitzGerald and Stünitz (1993) and Okudaira et al. (1995), these characteristics allow the maximum temperature estimation at $550^{\circ} \mathrm{C}$ for deformation in the studied shear zones. This is compatible with the minimum temperature required for ductile deformations of $\mathrm{K}$-feldspars, i.e. $550^{\circ} \mathrm{C}$ (FitzGerald \& Stünitz 1993, among others). Microstructural and $\mathrm{C}$-axis data suggest that deformations at $\mathrm{D}_{\mathrm{e}}$ shear zones are ductile-ruptile and were developed under conditions of greenschist facies.

Post-collisional granitoids were found at not only the Araçuaí Orogen, but also southwards from this orogen at the Ribeira Belt, which were interpreted by Valeriano et al. (2011) as being associated with the orogenic collapse during the Cambrian. Thus, considering the Ar-Ar ages of cooling achieved in this study, which varied between 480 and $490 \mathrm{Ma}$, and the ages obtained by Pedrosa-Soares 


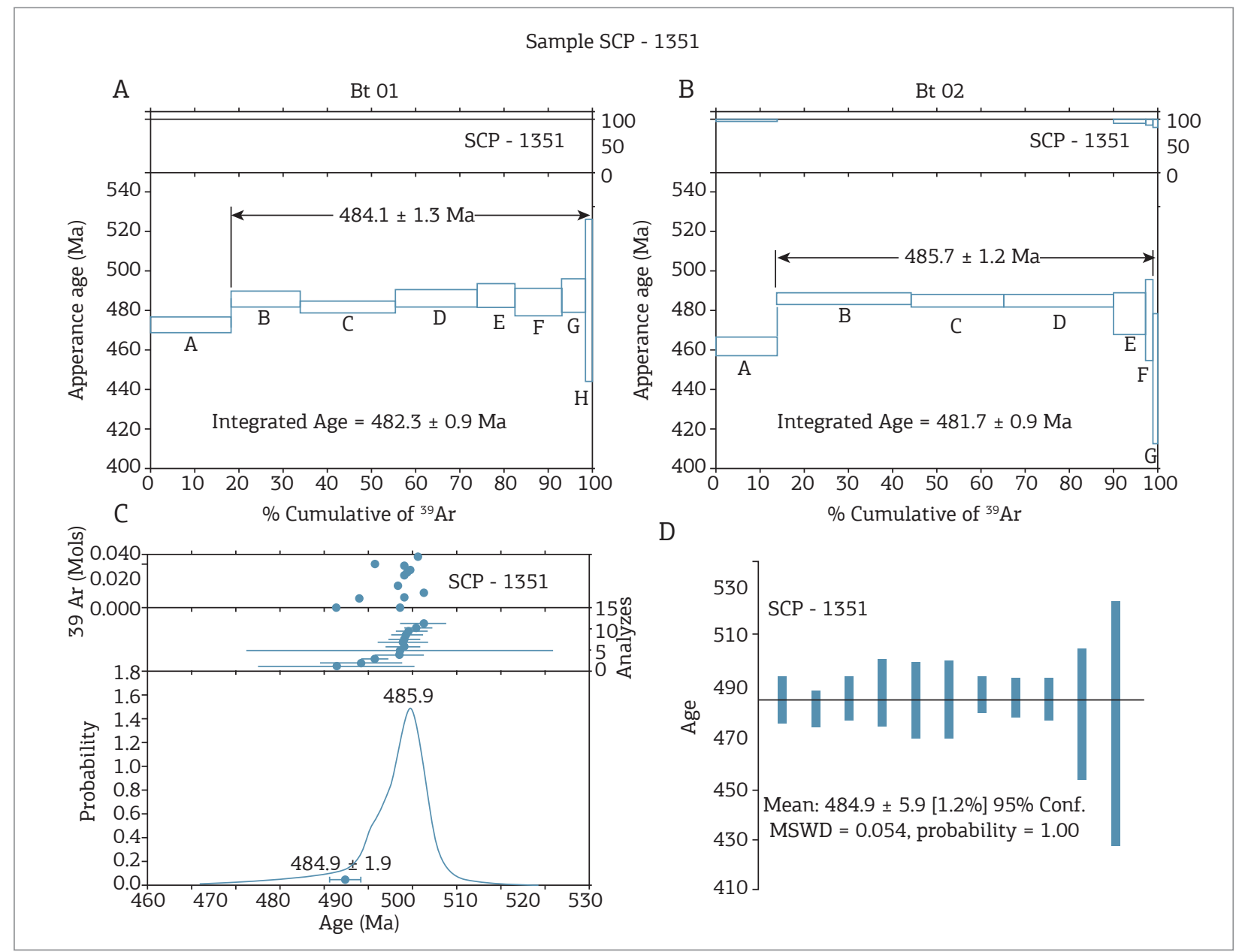

Figure 16. Results of the Ar-Ar analyses for sample SCP-1351.

et al. (2011) and Valeriano et al. (2011), for post-collisional granitoids crystallization in the Araçuaí-West Congo Orogen and in the Ribeira Belt, respectively, evidence suggest that by the end of the Cambrian, the crustal thickening generated by the collisions linked to the formation of Western Gondwana was followed by a regional extension that spread to the continental domains, i.e. to Paramirim Corridor (Fig. 18). Hence, the temperature associated with the formation of the extensional shear zones and with metamorphism, would have progressively decreased southwards, after the development of an extensive anatexis, directed northwards, and the formation of brittle-ductile to ductile-brittle normal shear zones.

\section{CONCLUSIONS}

Although compressional structures associated with the inversion of Paramirim Aulacogen, which occurred in the Ediacaran, predominate in the Paramirim Corridor, normal shear zones with a rich array of structures can be described reactivating the compressional structures. In these zones, the movement indicators are $\mathrm{S} / \mathrm{C}$ structures, while a down dip mineral stretching lineation can also be identified. The structural framework that was surveyed demonstrated a strong control over past structures in the nucleation of the extensional shear zones, which rotated the nucleated elements in the compressional phase.

The microstructural analysis demonstrated features that suggest the presence of processes involving the plastic deformation and dissolution by quartz pressure, as well as brittle fracturing of K-feldspar and intense transformation of K-feldspar and amphibolite into white mica and chlorite, respectively. The quartz $\mathrm{C}$-axis distribution and the deformation processes might show metamorphic conditions with temperatures below $550^{\circ} \mathrm{C}$.

The paleostress studied revealed a regimen varying between radial and pure extension. The Ar-Ar ages obtained from biotite samples of the extensional shear zones were established between 480 and $490 \mathrm{Ma}$. 
Table 3. Analytical data for sample SCP-711 in Lagoa Real Intrusive Suite. UTM coordinates (Córrego Alegre Datum): 23 L, 794148/8508976.

\begin{tabular}{|c|c|c|c|c|c|c|c|c|c|c|}
\hline N Power & $40 A r^{*}$ & $40 \mathrm{Ar}$ & $\pm \sigma 40$ & 39Ar & $\pm \sigma 39$ & 38Ar & $\pm \sigma 38$ & 37Ar & $\pm \sigma 37$ & $36 \mathrm{Ar}$ \\
\hline (W) & (moles) & $(10-9 A)$ & $(10-9 A)$ & $(10-9 A)$ & $(10-9 A)$ & $(10-9 A)$ & $(10-9 A)$ & $(10-9 A)$ & $(10-12 \mathrm{~A})$ & $(10-13 A)$ \\
\hline $01 \mathrm{~A}-0.2$ & 1.7E-14 & 0.888607 & 0.000731 & 0.010484 & 0.000035 & 0.000167 & 0.000006 & 0.000030 & 0.000012 & 0.000061 \\
\hline $01 B-0.2$ & 1.7E-14 & 0.875089 & 0.000561 & 0.009576 & 0.000043 & 0.000149 & 0.000011 & 0.000016 & 0.000010 & 0.000018 \\
\hline $01 C-0.3$ & $1.8 \mathrm{E}-14$ & 0.954989 & 0.000461 & 0.010328 & 0.000049 & 0.000155 & 0.000006 & 0.000022 & 0.000008 & 0.000042 \\
\hline 01D - 0.5 & $1.2 \mathrm{E}-14$ & 0.614583 & 0.000491 & 0.006700 & 0.000068 & 0.000096 & 0.000006 & 0.000007 & 0.000011 & 0.000018 \\
\hline $01 \mathrm{E}-0.6$ & $6.3 \mathrm{E}-15$ & 0.328489 & 0.000282 & 0.003570 & 0.000029 & 0.000071 & 0.000007 & 0.000038 & 0.000011 & 0.000021 \\
\hline $01 F-0.8$ & 8.3E-15 & 0.438005 & 0.000352 & 0.004685 & 0.000036 & 0.000073 & 0.000010 & 0.000014 & 0.000008 & 0.000020 \\
\hline $01 G-1.2$ & $2.9 \mathrm{E}-15$ & 0.151701 & 0.000163 & 0.001648 & 0.000027 & 0.000002 & 0.000009 & -0.000001 & 0.000012 & -0.000014 \\
\hline \multirow[t]{2}{*}{$01 \mathrm{H}-2.8$} & $1.9 \mathrm{E}-15$ & 0.097732 & 0.000114 & 0.001093 & 0.000014 & 0.000040 & 0.000006 & 0.000016 & 0.000011 & 0.000015 \\
\hline & $\sum 8.3^{\mathrm{E}-14}$ & & & & & & & & & \\
\hline
\end{tabular}

Plateau Age (steps B; C; D; E e F)

\begin{tabular}{|c|c|c|c|c|c|c|c|c|c|c|}
\hline $02 \mathrm{~A}-0.2$ & 2.7E-14 & 1.426779 & 0.000711 & 0.016779 & 0.000055 & 0.000224 & 0.000014 & -0.000033 & 0.000006 & 0.000006 \\
\hline O2B -0.2 & 2.9E-14 & 1.529240 & 0.001000 & 0.016814 & 0.000037 & 0.000192 & 0.000014 & -0.000035 & 0.000007 & -0.000014 \\
\hline $02 C-0.3$ & $3.4 \mathrm{E}-14$ & 1.773626 & 0.002000 & 0.019166 & 0.000059 & 0.000247 & 0.000011 & -0.000011 & 0.000007 & 0.000018 \\
\hline O2D - 0.5 & 3.0E-14 & 1.567509 & 0.000950 & 0.017051 & 0.000061 & 0.000232 & 0.000015 & 0.000013 & 0.000009 & 0.000002 \\
\hline O2E - 0.7 & 8.7E-15 & 0.457902 & 0.000581 & 0.005072 & 0.000045 & 0.000073 & 0.000010 & -0.000010 & 0.000006 & -0.000005 \\
\hline O2F - 1.2 & 3.7E-15 & 0.194401 & 0.000163 & 0.002229 & 0.000028 & 0.000002 & 0.000012 & -0.000038 & 0.000011 & -0.000034 \\
\hline \multirow[t]{2}{*}{$02 G-3.2$} & 5.3E-15 & 0.276311 & 0.000252 & 0.003328 & 0.000031 & 0.000049 & 0.000010 & -0.000009 & 0.000010 & 0.000001 \\
\hline & $\Sigma 1.4^{\mathrm{E}-13}$ & & & & & & & & & \\
\hline
\end{tabular}

\begin{tabular}{l|c|c|c|c|c|c|c}
\hline Standart: & & Lab \# : GR-006 & Age: $28.02 \mathrm{Ma}$ & \multicolumn{2}{|c|}{ D1: $1.0064 \pm 0.0025$} & HEATING: 11 S \\
\hline & \multicolumn{2}{|c|}{ Irradiation coordinates: $\mathrm{x}=0.53 \mathrm{~cm} ; \mathrm{y}=0.85 \mathrm{~cm} ; \mathrm{z}=0.31 \mathrm{~cm}$} & & \\
\hline
\end{tabular}

Explanatios

D1: Mass discrimination per AMU based on pawer law

$\Delta \mathrm{t} 2$ : Time interval (days) between end of irradiation and beginning of analysis

Blank Type3. Ave=average; LR=linear regression versus time

Constant used

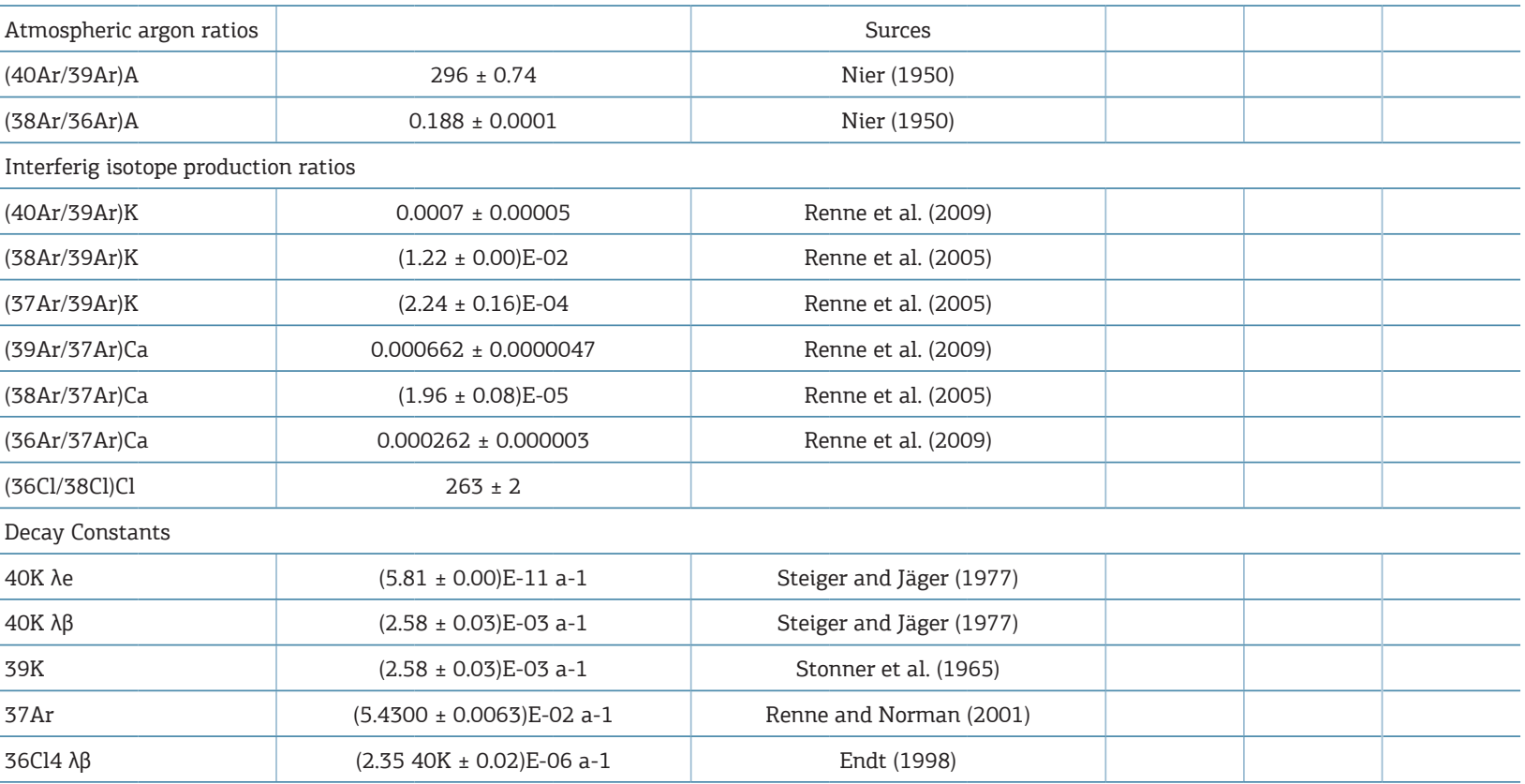


Table 3. Continuation.

\begin{tabular}{|c|c|c|c|c|c|c|c|c|}
\hline N Power & $\pm \sigma 36$ & $\% 40 A r^{*}$ & 40Ar*/ & $\pm \sigma$ & $40 \mathrm{Ar}^{*}$ & $40 \mathrm{Ar}^{*}$ & Age & $\pm \sigma$ \\
\hline$(\mathrm{W})$ & $(10-14 A)$ & & 39Ark & & Cumulative & $\%$ Cumulative & (Ma) & (Ma) \\
\hline $01 \mathrm{~A}-0.2$ & 0.000005 & $2.0 \mathrm{E}+01$ & 83.39909 & 0.35571 & 1.7E-14 & $2.0 \mathrm{E}+01$ & 450.8 & 1.7 \\
\hline $01 B-0.2$ & 0.000005 & $2.0 \mathrm{E}+01$ & 91.16364 & 0.46528 & 3.4E-14 & $4.1 \mathrm{E}+01$ & 487.6 & 2.2 \\
\hline $01 C-0.3$ & 0.000006 & $2.2 \mathrm{E}+01$ & 91.62115 & 0.48997 & 5.2E-14 & $6.2 \mathrm{E}+01$ & 489.7 & 2.3 \\
\hline $01 \mathrm{D}-0.5$ & 0.000005 & $1.4 \mathrm{E}+01$ & 91.24931 & 0.98370 & 6.3E-14 & $7.7 \mathrm{E}+01$ & 488.0 & 4.6 \\
\hline $01 E-0.6$ & 0.000006 & $7.6 \mathrm{E}+00$ & 90.88746 & 0.90834 & 7.0E-14 & $8.4 \mathrm{E}+01$ & 486.3 & 4.3 \\
\hline $01 F-0.8$ & 0.000006 & $1.0 \mathrm{E}+01$ & 92.65694 & 0.82524 & $7.8 \mathrm{E}-14$ & $9.4 \mathrm{E}+01$ & 494.6 & 3.9 \\
\hline $01 G-1.2$ & 0.000006 & $3.5 \mathrm{E}+00$ & 94.80014 & 1.89882 & 8.1E-14 & $9.8 \mathrm{E}+01$ & 504.6 & 8.8 \\
\hline $01 \mathrm{H}-2.8$ & 0.000006 & $2.2 \mathrm{E}+00$ & 86.29737 & 1.96132 & 8.3E-14 & $1.0 \mathrm{E}+02$ & 464.7 & 9.3 \\
\hline \multicolumn{9}{|c|}{ Plateau Age (steps B; C; D; E e F) } \\
\hline $02 \mathrm{~A}-0.2$ & 0.000005 & $2.0 \mathrm{E}+01$ & 85.44078 & 0.33266 & 2.7E-14 & $2.0 \mathrm{E}+01$ & 460.6 & 1.6 \\
\hline O2B -0.2 & 0.000005 & $2.1 \mathrm{E}+01$ & 91.71756 & 0.27523 & 5.6E-14 & $4.1 \mathrm{E}+01$ & 490.2 & 1.3 \\
\hline $02 C-0.3$ & 0.000006 & $2.5 \mathrm{E}+01$ & 92.81429 & 0.35111 & $9.0 \mathrm{E}-14$ & $6.5 \mathrm{E}+01$ & 495.3 & 1.7 \\
\hline $02 \mathrm{D}-0.5$ & 0.000005 & $2.2 \mathrm{E}+01$ & 92.46394 & 0.37857 & $1.2 \mathrm{E}-13$ & $8.7 \mathrm{E}+01$ & 493.7 & 1.8 \\
\hline O2E - 0.7 & 0.000005 & $6.3 \mathrm{E}+00$ & 91.08495 & 0.87519 & 1.3E-13 & $9.4 \mathrm{E}+01$ & 487.2 & 4.1 \\
\hline $02 \mathrm{~F}-1.2$ & 0.000005 & $2.7 \mathrm{E}+00$ & 92.04704 & 1.32553 & $1.3 \mathrm{E}-13$ & $9.6 \mathrm{E}+01$ & 491.7 & 6.2 \\
\hline $02 G-3.2$ & 0.000006 & $3.8 \mathrm{E}+00$ & 83.45596 & 0.93332 & $1.4 \mathrm{E}-13$ & $1.0 \mathrm{E}+02$ & 451.1 & 4.5 \\
\hline
\end{tabular}

Plateau Age (steps B; C; D; E e F)

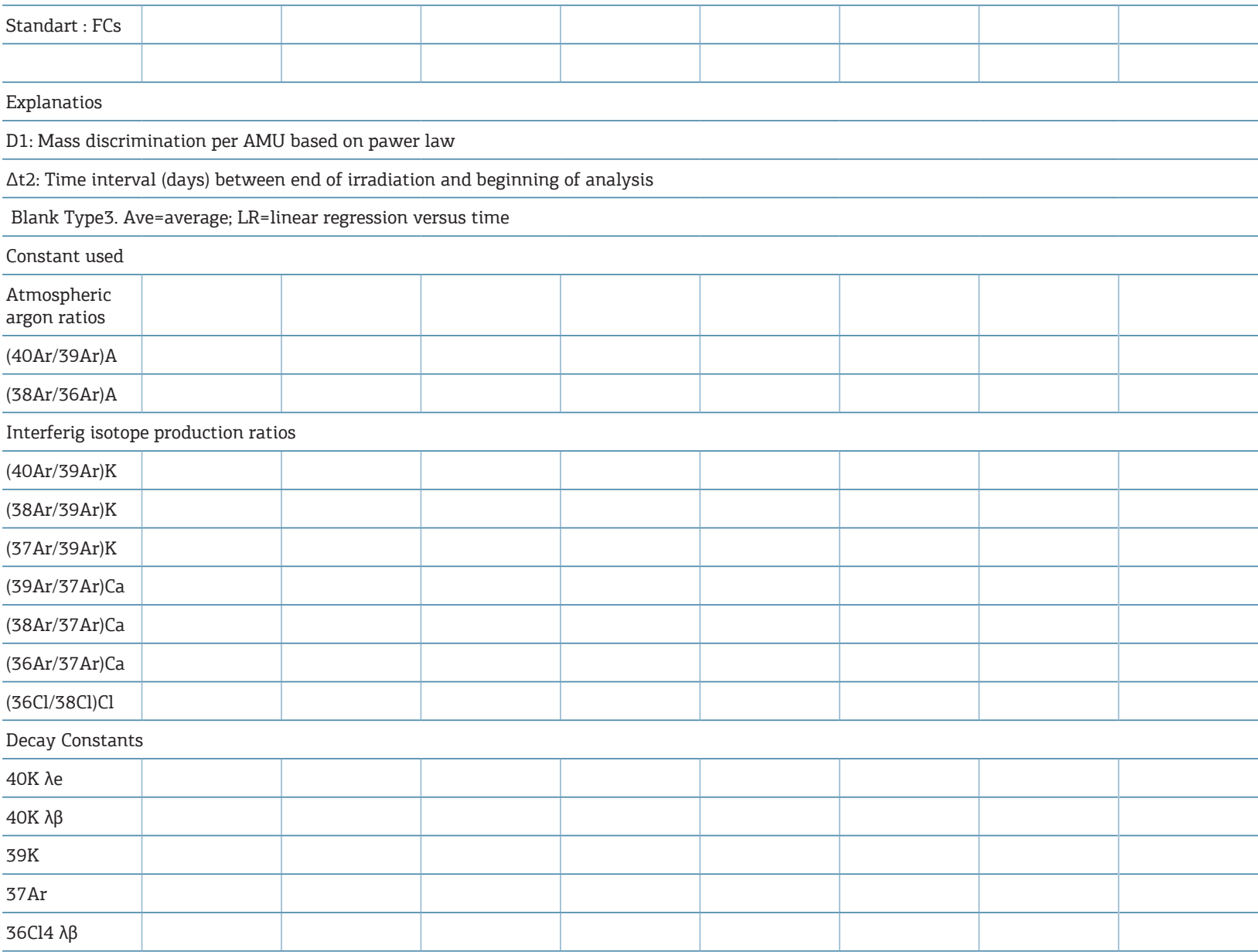


Table 4. Analytical data for sample SCP-1351 in the basement of the Paramirim Corridor. UTM coordinates (Córrego Alegre Datum): 24 L, 252896/8339686.

\begin{tabular}{|c|c|c|c|c|c|c|c|c|c|c|}
\hline N Power & 40Ar* & $40 A r$ & $\pm \sigma 40$ & 39Ar & $\pm \sigma 39$ & $38 \mathrm{Ar}$ & $\pm \sigma 38$ & $37 \mathrm{Ar}$ & $\pm \sigma 37$ & 36Ar \\
\hline (W) & (moles) & $(10-9 A)$ & $(10-9 A)$ & $(10-9 A)$ & $(10-9 A)$ & $(10-9 A)$ & $(10-9 A)$ & $(10-9 A)$ & $(10-12 \mathrm{~A})$ & $(10-13 \mathrm{~A})$ \\
\hline $01 \mathrm{~A}-0.2$ & $2.4 \mathrm{E}-14$ & 1.277534 & 0.000840 & 0.014522 & 0.000070 & 0.000165 & 0.000007 & -0.000039 & 0.000010 & 0.000012 \\
\hline 01B - 0.2 & 2.2E-14 & 1.157440 & 0.000681 & 0.012804 & 0.000048 & 0.000149 & 0.000006 & -0.000034 & 0.000009 & 0.000003 \\
\hline $01 C-0.3$ & 2.9E-14 & 1.554251 & 0.000830 & 0.017340 & 0.000050 & 0.000202 & 0.000007 & -0.000010 & 0.000010 & 0.000009 \\
\hline $01 \mathrm{D}-0.5$ & $2.6 \mathrm{E}-14$ & 1.355744 & 0.000761 & 0.014999 & 0.000055 & 0.000150 & 0.000007 & -0.000013 & 0.000009 & -0.000008 \\
\hline $01 E-0.6$ & $1.2 \mathrm{E}-14$ & 0.631469 & 0.000651 & 0.006975 & 0.000037 & 0.000065 & 0.000007 & -0.000036 & 0.000008 & -0.000009 \\
\hline $01 F-0.8$ & $1.5 \mathrm{E}-14$ & 0.775932 & 0.000651 & 0.008568 & 0.000057 & 0.000088 & 0.000007 & -0.000002 & 0.000009 & 0.000010 \\
\hline $01 G-1.2$ & 7.7E-15 & 0.407224 & 0.000371 & 0.004530 & 0.000028 & 0.000036 & 0.000007 & -0.000023 & 0.000011 & -0.000007 \\
\hline \multirow[t]{2}{*}{$01 \mathrm{H}-2.8$} & $1.3 \mathrm{E}-15$ & 0.072098 & 0.000391 & 0.000768 & 0.000032 & 0.000016 & 0.000009 & 0.000001 & 0.000009 & 0.000010 \\
\hline & $\Sigma 1.4^{\mathrm{E}-13}$ & & & & & & & & & \\
\hline
\end{tabular}

Plateau Age (steps B: C; D; E; F e G):

\begin{tabular}{|c|c|c|c|c|c|c|c|c|c|c|}
\hline $02 \mathrm{~A}-0.1$ & 1.5E-14 & 0.798383 & 0.000631 & 0.009152 & 0.000041 & 0.000145 & 0.000006 & 0.000014 & 0.000019 & 0.000061 \\
\hline $02 B-0.2$ & $3.5 \mathrm{E}-14$ & 1.822626 & 0.001001 & 0.020093 & 0.000053 & 0.000247 & 0.000007 & 0.000010 & 0.000012 & 0.000017 \\
\hline $02 C-0.3$ & 2.3E-14 & 1.230268 & 0.000621 & 0.013574 & 0.000041 & 0.000188 & 0.000007 & 0.000004 & 0.000012 & 0.000021 \\
\hline $02 \mathrm{D}-0.5$ & $2.8 \mathrm{E}-14$ & 1.486212 & 0.000741 & 0.016448 & 0.000057 & 0.000209 & 0.000008 & -0.000005 & 0.000010 & 0.000015 \\
\hline O2E - 0.7 & 8.3E-15 & 0.435802 & 0.000421 & 0.004816 & 0.000057 & 0.000102 & 0.000010 & 0.000021 & 0.000015 & 0.000030 \\
\hline $02 \mathrm{~F}-1.1$ & 2.0E-15 & 0.103051 & 0.000154 & 0.001131 & 0.000019 & 0.000036 & 0.000009 & -0.000002 & 0.000010 & 0.000012 \\
\hline \multirow[t]{2}{*}{$02 \mathrm{G}-3.0$} & $8.8 \mathrm{E}-16$ & 0.046742 & 0.000089 & 0.000539 & 0.000015 & 0.000005 & 0.000014 & -0.000008 & 0.000009 & 0.000009 \\
\hline & $\sum 1.1^{\mathrm{E}-13}$ & & & & & & & & & \\
\hline \multicolumn{11}{|c|}{ Plateau Age (steps B; C; D; E e F): } \\
\hline \multicolumn{2}{|c|}{ Standart : FCs } & \multicolumn{2}{|c|}{ Lab \# : GR-006 } & \multicolumn{2}{|c|}{ Age: $28.02 \mathrm{Ma}$} & \multicolumn{3}{|c|}{$\mathrm{D} 1: 1.0064 \pm 0.0025$} & \multicolumn{2}{|c|}{ HEATING: $11 \mathrm{~S}$} \\
\hline \multicolumn{6}{|c|}{ Irradiation coordinates: $\mathrm{x}=0.53 \mathrm{~cm} ; \mathrm{y}=0.85 \mathrm{~cm} ; \mathrm{z}=0.31 \mathrm{~cm}$} & & & & & \\
\hline
\end{tabular}

D1: Mass discrimination per AMU based on pawer law

$\Delta \mathrm{t} 2$ : Time interval (days) between end of irradiation and beginning of analysis

Blank Type3. Ave=average; LR=linear regression versus time

Constant used

Atmospheric argon ratios

(40Ar/39Ar)A

(38Ar/36Ar)A

$296 \pm 0.74$

Surces

$0.188 \pm 0.0001$

Nier (1950)

Interferig isotope production ratios

\begin{tabular}{l|c|c|c|c|}
\hline$(40 \mathrm{Ar} / 39 \mathrm{Ar}) \mathrm{K}$ & $0.0007 \pm 0.00005$ & Renne et al. (2009) & & \\
\hline$(38 \mathrm{Ar} / 39 \mathrm{Ar}) \mathrm{K}$ & $(1.22 \pm 0.00) \mathrm{E}-02$ & Renne et al. (2005) & & \\
\hline$(37 \mathrm{Ar} / 39 \mathrm{Ar}) \mathrm{K}$ & $(2.24 \pm 0.16) \mathrm{E}-04$ & Renne et al. (2005) & & \\
\hline$(39 \mathrm{Ar} / 37 \mathrm{Ar}) \mathrm{Ca}$ & $0.000662 \pm 0.0000047$ & Renne et al. (2009) & & \\
\hline$(38 \mathrm{Ar} / 37 \mathrm{Ar}) \mathrm{Ca}$ & $(1.96 \pm 0.08) \mathrm{E}-05$ & Renne et al. (2005) & & \\
\hline$(36 \mathrm{Ar} / 37 \mathrm{Ar}) \mathrm{Ca}$ & $0.000262 \pm 0.000003$ & Renne et al. (2009) & & \\
\hline$(36 \mathrm{Cl} / 38 \mathrm{Cl}) \mathrm{Cl}$ & $263 \pm 2$ & & & \\
\hline Decay Constants & $(5.81 \pm 0.00) \mathrm{E}-11 \mathrm{a}-1$ & Steiger and Jäger (1977) & & \\
\hline $40 \mathrm{~K} \lambda \mathrm{e}$ & $(2.58 \pm 0.03) \mathrm{E}-03 \mathrm{a}-1$ & Steiger and Jäger (1977) & & \\
\hline $40 \mathrm{~K} \lambda \beta$ & $(2.58 \pm 0.03) \mathrm{E}-03 \mathrm{a}-1$ & Stonner et al. (1965) & & \\
\hline $39 \mathrm{~K}$ & $(5.4300 \pm 0.0063) \mathrm{E}-02 \mathrm{a}-1$ & Renne and Norman (2001) & & \\
\hline $37 \mathrm{Ar}$ & $(2.3540 \mathrm{~K} \pm 0.02) \mathrm{E}-06 \mathrm{a}-1$ & Endt (1998) & & \\
\hline $36 \mathrm{Cl} 4 \lambda \beta$ & & & \\
\hline
\end{tabular}

Continue... 
Table 4. Continuation.

\begin{tabular}{|c|c|c|c|c|c|c|c|c|}
\hline N Power & $\pm \sigma 36$ & $\% 40$ Ar $^{*}$ & $40 \mathrm{Ar}^{*} /$ & $\pm \sigma$ & $40 \mathrm{Ar}^{*}$ & $40 \mathrm{Ar}^{*}$ & Age & $\pm \sigma$ \\
\hline$(\mathrm{W})$ & $(10-14 \mathrm{~A})$ & & 39Ark & & Cumulative & $\%$ Cumulative & $(\mathrm{Ma})$ & (Ma) \\
\hline $01 \mathrm{~A}-0.2$ & 0.000006 & $1.8 \mathrm{E}+01$ & 88.00687 & 0.46785 & 2.4E-14 & $1.8 \mathrm{E}+01$ & 472.7 & 2.2 \\
\hline 01B - 0.2 & 0.000006 & $1.6 \mathrm{E}+01$ & 90.61531 & 0.39749 & $4.6 \mathrm{E}-14$ & $3.4 \mathrm{E}+01$ & 485.0 & 1.9 \\
\hline $01 C-0.3$ & 0.000005 & $2.1 \mathrm{E}+01$ & 89.75033 & 0.31172 & $7.6 \mathrm{E}-14$ & $5.5 \mathrm{E}+01$ & 481.0 & 1.5 \\
\hline $01 \mathrm{D}-0.5$ & 0.000005 & $1.9 \mathrm{E}+01$ & 90.81448 & 0.38093 & $1.0 \mathrm{E}-13$ & $7.4 \mathrm{E}+01$ & 486.0 & 1.8 \\
\hline $01 \mathrm{E}-0.6$ & 0.000005 & $8.8 \mathrm{E}+00$ & 91.18965 & 0.55434 & $1.1 \mathrm{E}-13$ & $8.3 \mathrm{E}+01$ & 487.7 & 2.6 \\
\hline $01 F-0.8$ & 0.000006 & $1.1 \mathrm{E}+01$ & 90.48872 & 0.65784 & $1.3 \mathrm{E}-13$ & $9.3 \mathrm{E}+01$ & 484.4 & 3.1 \\
\hline $01 G-1.2$ & 0.000006 & $5.6 \mathrm{E}+00$ & 90.62318 & 0.68158 & $1.4 \mathrm{E}-13$ & $9.9 \mathrm{E}+01$ & 485.1 & 3.2 \\
\hline $01 \mathrm{H}-2.8$ & 0.000005 & $9.6 \mathrm{E}-01$ & 90.51482 & 4.38713 & $1.4 \mathrm{E}-13$ & $1.0 \mathrm{E}+02$ & 484.6 & 20.6 \\
\hline \multicolumn{9}{|c|}{ Plateau Age (steps B: C; D; E; F e G): } \\
\hline $02 \mathrm{~A}-0.1$ & 0.000006 & $1.4 \mathrm{E}+01$ & 85.88734 & 0.47223 & 1.5E-14 & $1.4 \mathrm{E}+01$ & 462.7 & 2.3 \\
\hline 02B -0.2 & 0.000006 & $3.1 \mathrm{E}+01$ & 91.01627 & 0.30332 & 5.0E-14 & $4.4 \mathrm{E}+01$ & 486.9 & 1.5 \\
\hline $02 C-0.3$ & 0.000005 & $2.1 \mathrm{E}+01$ & 90.72214 & 0.33803 & 7.3E-14 & $6.5 \mathrm{E}+01$ & 485.5 & 1.6 \\
\hline $02 \mathrm{D}-0.5$ & 0.000005 & $2.5 \mathrm{E}+01$ & 90.63126 & 0.36414 & $1.0 \mathrm{E}-13$ & $9.0 \mathrm{E}+01$ & 485.1 & 1.7 \\
\hline $02 \mathrm{E}-0.7$ & 0.000005 & $7.4 \mathrm{E}+00$ & 89.35449 & 1.13830 & $1.1 \mathrm{E}-13$ & $9.7 \mathrm{E}+01$ & 479.1 & 5.4 \\
\hline $02 \mathrm{~F}-1.1$ & 0.000006 & $1.7 \mathrm{E}+00$ & 88.68401 & 2.13793 & $1.1 \mathrm{E}-13$ & $9.9 \mathrm{E}+01$ & 475.9 & 10.1 \\
\hline $02 G-3.0$ & 0.000005 & 7.9E-01 & 82.46083 & 3.46516 & $1.1 \mathrm{E}-13$ & $1.0 \mathrm{E}+02$ & 446.3 & 16.6 \\
\hline \multicolumn{9}{|c|}{ Plateau Age (steps B; C; D; E e F): } \\
\hline \multicolumn{9}{|c|}{ Standart : FCs } \\
\hline \multicolumn{9}{|c|}{ Irradiation coordinates: $\mathrm{x}=0.53 \mathrm{~cm} ; \mathrm{y}=0.85 \mathrm{~cm} ; \mathrm{z}=0.31 \mathrm{~cm}$} \\
\hline \multicolumn{9}{|c|}{ Explanatios } \\
\hline \multicolumn{9}{|c|}{ D1: Mass discrimination per AMU based on pawer law } \\
\hline \multicolumn{9}{|c|}{$\Delta \mathrm{t} 2$ : Time interval (days) between end of irradiation and beginning of analysis } \\
\hline \multicolumn{9}{|c|}{ Blank Type3. Ave=average; LR=linear regression versus time } \\
\hline \multicolumn{9}{|c|}{ Constant used } \\
\hline \multicolumn{9}{|c|}{$\begin{array}{l}\text { Atmospheric } \\
\text { argon ratios }\end{array}$} \\
\hline \multicolumn{9}{|c|}{ (40Ar/39Ar)A } \\
\hline \multicolumn{9}{|c|}{ (38Ar/36Ar)A } \\
\hline \multicolumn{9}{|c|}{ Interferig isotope production ratios } \\
\hline \multicolumn{9}{|c|}{$(40 \mathrm{Ar} / 39 \mathrm{Ar}) \mathrm{K}$} \\
\hline \multicolumn{9}{|c|}{ (38Ar/39Ar)K } \\
\hline \multicolumn{9}{|c|}{$(37 \mathrm{Ar} / 39 \mathrm{Ar}) \mathrm{K}$} \\
\hline \multicolumn{9}{|c|}{ (39Ar/37Ar)Ca } \\
\hline \multicolumn{9}{|c|}{$(38 \mathrm{Ar} / 37 \mathrm{Ar}) \mathrm{Ca}$} \\
\hline \multicolumn{9}{|c|}{$(36 \mathrm{Ar} / 37 \mathrm{Ar}) \mathrm{Ca}$} \\
\hline \multicolumn{9}{|c|}{$(36 \mathrm{Cl} / 38 \mathrm{Cl}) \mathrm{Cl}$} \\
\hline \multicolumn{9}{|c|}{ Decay Constants } \\
\hline \multicolumn{9}{|l|}{$40 \mathrm{~K} \lambda \mathrm{e}$} \\
\hline \multicolumn{9}{|l|}{$40 \mathrm{~K} \lambda \beta$} \\
\hline $39 \mathrm{~K}$ & & & & & & & & \\
\hline $37 \mathrm{Ar}$ & & & & & & & & \\
\hline $36 \mathrm{Cl} 4 \lambda \beta$ & & & & & & & & \\
\hline
\end{tabular}




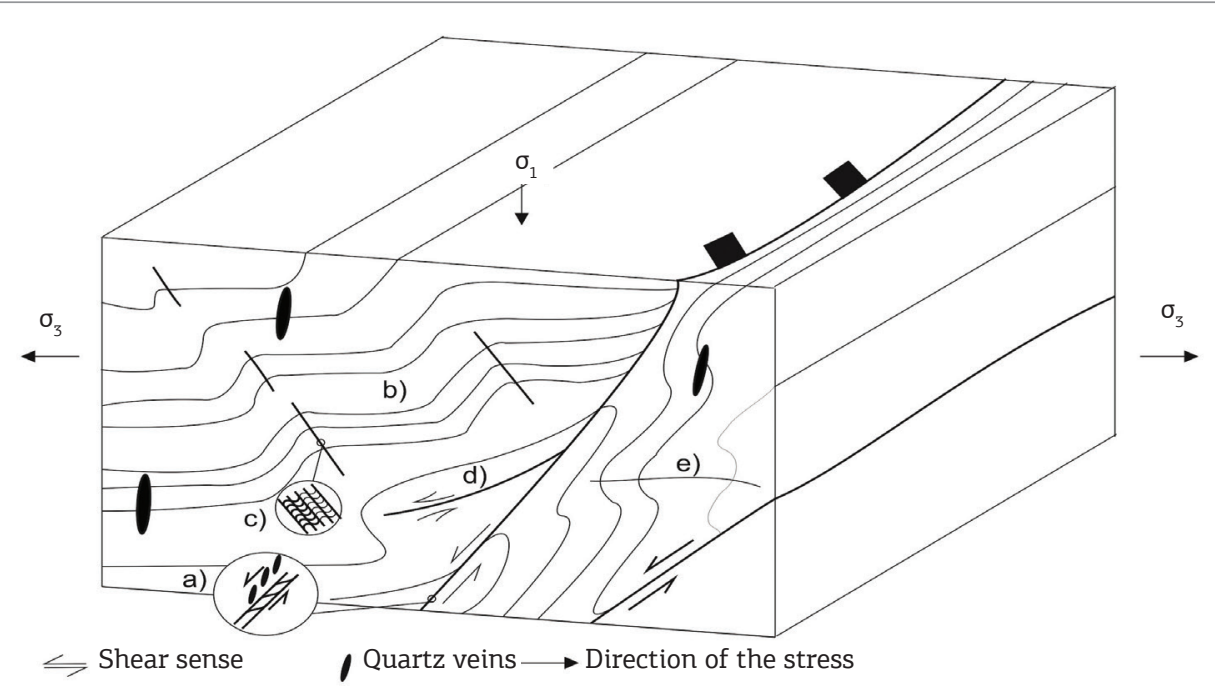

Figure 17. Schematic model for the $\mathrm{D}_{\mathrm{e}}$ extensional structures and interpretation of paleostress. (A) Normal shear zones with quartz veins. (B) Asymmetrical folds and quartz veins. (C) Crenulation cleavage. (D) Fold propagation fault. (E) Recumbent folds.

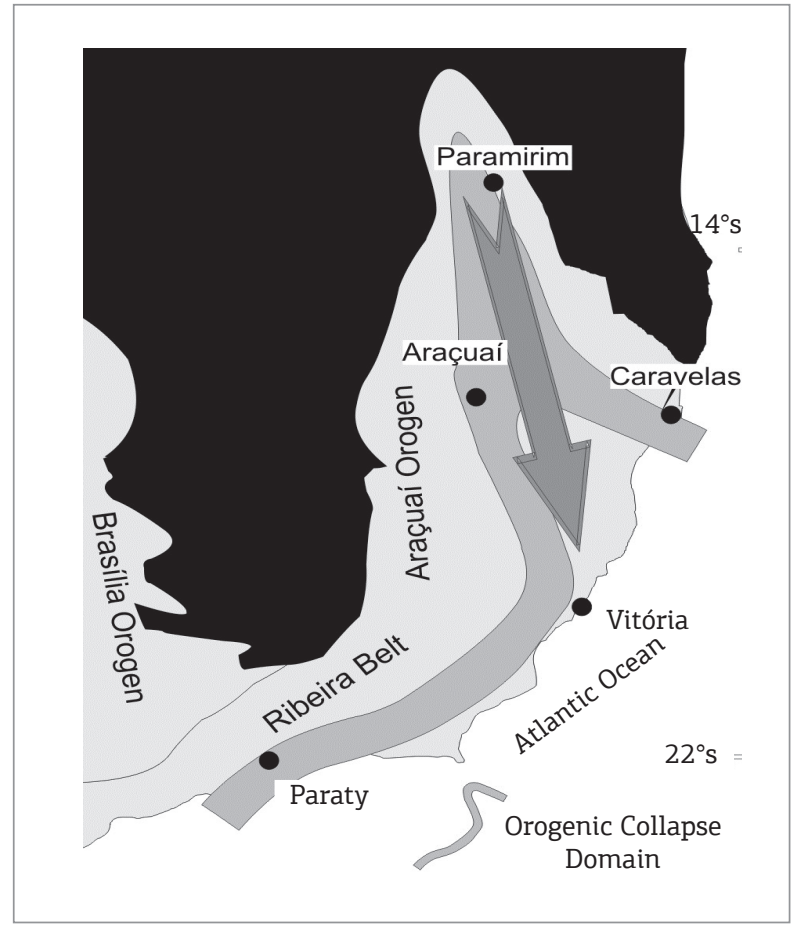

Figure 18. Interpretation of the domain of occurrence of the features related to the gravitational collapse of Araçuaí-West Congo Orogen and Ribeira Belt. The arrow indicates the increase in metamorphism and deformation temperature. Modified from Valeriano et al. (2011).
The field relations and the ages obtained suggest that the set of extensional structures described in the present study may be associated with the gravitational collapse of the Araçuaí-West Congo Orogen and, regionally, may represent the most distal and coldest sector of this collapse.

\section{ACKNOWLEDGEMENTS}

The authors would like to express their gratitude to the Companhia de Pesquisa de Recursos Minerais (CPRM), the Companhia Baiana de Pesquisa Mineral (CBPM), and the Graduation Program of Universidade Federal da Bahia for their support towards the research. In addition, they are thankful for the Brazilian National Counsel of Technological and Scientific Development (CNPq) for the Fellowship Grant (Processes 307590/2009-7 and 306744/2012-0) given to Simone C. P. Cruz and for the Universal Project Call (Process 473806/2010-0). They also thank doctor Damien Delvaux of the Royal Museum for Central Africa, Tervuren, Belgium, for making the WinTensor software freely available. In addition, they also would like to thank sincerely the anonymous reviewer for the important contributions to improve the quality of the manuscript. 


\section{REFERENCES}

Alkmim F.F., Brito Neves B.B., Alves J.A.C. 1993. Arcabouço tectônico do Cráton do São Francisco - uma revisão. In: Dominguez J.M. \& Misi A. (eds.) O cráton do São Francisco. Reunião preparatória do II Simpósio sobre o cráton do São Francisco. Salvador, SBG/ Núcleo BA/ SE/SGM/CNPq, p. 45-62

Alkmim F.F., Marshak S., Pedrosa-Soares A.C., Peres G.G., Cruz S.C.P. Whittington A. 2006. Kinematic evolution of the Aracuaí-West Congo orogen in Brazil and Africa: Nutcracker tectonics during the Neoproterozoic assembly of Gondwana. Precambrian Research, 149:43-64

Allmendinger R.W., Sharp J.W., Von Tish D., Serpa L., Brown L., Kaufmans S., Olivier J., Smith R.B. 1983. Cenozoic and Mesozoic structures of the Eastern Basin and range Province, Utah, from COCORP seismic reflection data. Geology, 11:532-536.

Babinsky M., Pedrosa-Soares A.C., Trindade R.I.F., Martins M.C.M., Noce L.D. 2011. Neoproterozoic glacial deposits from the Araçuaí orogen, Brazil: Age, provenance and correlations with the São Francisco craton and West Congo belt. Gondwana Research, 2(3):1-15.

Bastos Leal L.R., Teixeira W., Cunha J.C., Leal A.B.M., Macambira M.J.B., Rosa M.L.S. 2000. Isotopic signatures of paleoproterozoic granitoids of the Gavião block and implications for the evolution of the São Francisco craton, Bahia, Brazil. Revista Brasileira de Geociências, 30:66-69.

Bastos Leal L.R., Teixeira W., Cunha J.C., Macambira M.J.B. 1998. Archean tonalitic-trondhjemitic and granitic plutonism in the Gavião block, São Francisco Craton, Bahia, Brazil: Geochemical and geochronology characteristics. Revista Brasileira de Geociências, 2:209-220.

Beutner E.C. \& Diegel F.A. 1985. Determination of folds kinematics from syntectonics fibres in pressure shadows, Martinsburg Slates, New Jersey. American Journal of Science, 285:16-50.

Borge J.O., Cruz S.C.P., Barbosa J.S.F. 2015. Structural framework of the the Lagoa D'Anta mine area, iron-manganese Urandi-CaetitéLicínio de Almeida District, Bahia, Brasil. Brazilian Journal of Geology. In press.

Burke K. \& Dewey J.F. 1973. Plume-generated triple junctions: key indicators in applying plate tectonics to old rocks. Journal of Geology, 81:406-433.

Burke K. \& Whiteman A.J. 1973. Uplift, rifting and the breakup of Africa. In: Tarling D.H. \& Runcorn S.K. (eds.) Implications of continental drift to the Earth Sciences. London, Academy Press, p. 735-755.

Butler R., Tavarnelli E., Grasso M. 2006. Tectonic inversion and structural inheritance in mountain belts. Journal of Structural Geology, 28(11):1891-1892.

Charrier R., Baeza O., Elgueta S., Flynn J.J., Gans P., Kay S.M., Muñoz N., Zurita E. 2002. Evidence for Cenozoic extensional basin development and tectonic inversion south of the flat-slab segment, southern Central Andes, Chile $\left(33^{\circ}-36^{\circ}\right.$ S.L.). Journal of South American Earth Sciences, 15(1):117-139.

Chemale-Júnior F., Dussin I.A., Alkmim F.F., Martins M.S., Queiroga G., Armstrong R., Santos M.N. 2012. Unravelling a Proterozoic basin history through detrital zircon geochronology: the case of the Espinhaço Supergroup, Minas Gerais Brazil. Gondwana Research. 22:200-206

Cordani U.G., Iyer S.S., Taylor P.N., Kawashita K., Sato K., Mcreath I. 1992. $\mathrm{Pb}-\mathrm{Pb}, \mathrm{Rb}-\mathrm{Sr}$, and $\mathrm{K}-\mathrm{Ar}$ sistematic of the Lagoa Real uranium province (south-central Bahia, Brazil) and the Espinhaço Cycle (ca. 1.5-1.0 Ga). Journal of South American Earth Sciences, 1:33-46.
Cruz S.C.P. 2004. A interação tectônica entre o Aulacógeno do Paramirim e o Orógeno Araçuaí-Oeste Congo. Tese de Doutorado, Universidade Federal de Ouro Preto, Ouro Preto, 505 p.

Cruz S.C.P. \& Alkmim F.F. 2006. The tectonic interaction between the Paramirim Aulacogen and the Araçuaí Belt, São Francisco Craton region, Easter Brazil. Anais da Academia Brasileira de Ciências, 1:151-173.

Cruz S.C.P. \& Alkmim F.F. 2007a. A história de inversão do aulacógeno do Paramirim contada pela sinclinal de Ituaçu, extremo sul da Chapada Diamantina (BA). Revista Brasileira de Geociências, 37:92-110

Cruz S.C.P., Alkmim F.F., Leite C.M.M., Evangelista H.J., Cunha J.C., Matos E.C., Noce C.M., Marinho M.M. 2007b. Geologia e arcabouço estrutural do Complexo Lagoa Real, Vale do Paramirim, CentroOeste da Bahia. Revista Brasileira de Geociências, 37:28-146.

Cruz S.C.P., Dias V.M., Alkmim F.F. 2007c. A interação tectônica embasamento/cobertura em aulacógenos invertidos: um exemplo da Chapada Diamantina Ocidental. Revista Brasileira de Geociências, 37:111-127

Cruz S.C.P., Alkmim F.F., Pedreira A., Teixeira L., Pedrosa-Soares A.C., Gomes L.C.C., Souza J.S., Leal A.B.M. 2012. O Orógeno Araçuaí. In: Barbosa J.S.F., Mascarenhas J.F., Corrêa-Gomes L.C., Domingues J.M.L, Oliveira, J.S.S. (eds.) Geologia da Bahia. Pesquisa e Atualização de Dados. Salvador, CBPM, 2, p. 131-178.

Cunningham D. 2005. Active intracontinental transpressional mountain building in the Mongolian Altai: defining a new class of orogen. Earth and Planetary Science Letters, 240:436-444.

Cunningham D. 2013. Mountain building processes in intracontinental oblique deformation belts: lessons from the Gobi Corridor, Central Asia. Journal of Structural Geology, 46:255-282.

Danderfer Filho A. 2000. Geologia sedimentar e evolução tectônica do Espinhaço Setentrional, estado da Bahia. Tese de Doutoramento, Instituto de Geociências, Universidade Federal de Brasília, Brasília, 497 p.

Danderfer Filho A., DeWaele B., Pedreira A., Nalini H.A. 2009. New geochronological constraints on the geological evolution of Espinhaço basin within the São Francisco Craton - Brazil. Precambrian Research, 170:116-128.

Delvaux D. 2012. Release of program Win-Tensor 4.0 for tectonic stress inversion: statistical expression of stress parameters. EGU General Assembly, Vienna, 2012. Geophysical Research Abstracts, v. 14, EGU2012-5899.

Dewey J.F. \& Burke K. 1974. Hot Spot and continental break-up: implications for collisional orogeny. Geology, 2:57-60.

Dhahri F. \& Boukadi N. 2010. The evolution of pre-existing structures during the tectonic inversion process of the Atlas chain of Tunisia. Journal of African Earth Sciences, 56:139-149.

Durney D.W. \& Ramsay J.G. 1973. Incremental strain measured by syntectonic crystals growts. In: De Jong K.A. \& Scholten R. (eds.) Gravity and tectonics. Wiley, New York, p. 67-39.

Endt P.M. 1998. Supplement of energy levels of $A=44$ nuclei (VII). Nuclear Physics, A633:1-220.

Etchecopar A. \& Malavieille J. 1987. Computer models of pressure shadows: a method for strain measurement and shear sense determination. Journal of Structural Geology, 9:667-677.

Faccenna C., Nalpas T., Brum J.P., Davy P. 1995. The influence of preexisting thrust faults on normal fault geometry in nature and in experiments. Journal of Structural Geology, 8:1139-1149. 
Fettes D. \& Desmons J. 2007. Metamorphic rocks: a classification and glossary of terms: recommendations of the International Union of Geological Sciences Sub-commission on the Systematics of Metamorphic Rocks. Cambridge, Cambridge University Press, 244 p.

FitzGerald J.D. \& Stünitz H. 1993. Deformation of granitoids at low metamorphic grade I: Reactions and grain size reduction. Tectonophysics, 221:269-297.

Fleuty M.J. 1964. The descriptions of folds. Proceedings of the Geologists' Association, 75:461-492.

Guadagnin F., Chemale Jr. F., Magalhães A.J.C., Santana A., Dussin I., Takehara L. 2015. Age constraints on crystal-tuff from the Espinhaço Supergroup - Insight into the Paleoproterozoic to Mesoproterozoic intracratonic basin cycles of the Congo-São Francisco Craton. Gondwana Research, 27:363-376.

Guimarães J.T., Teixeira L.R., Silva M.G. Martins A.A.M., Filho E.L.A., Loureiro H.S.C., Arcanjo J.B., Dalton de Souza J., Neves J.P., Mascarenhas J.F., Melo R.C., Bento R.V. 2005. Datações U/Pb em rochas magmáticas intrusivas no Complexo Paramirim e no Rifte Espinhaço: uma contribuição ao estudo da Evolução Geocronológica da Chapada Diamantina. In: SBG/BA-SE, Simpósio do Cráton do São Francisco, 3, Anais de Resumos Expandidos, p. 159-161.

Guimarães J.T., Alkmim F.F., Cruz S.C.P. 2012. Supergrupos Espinhaço e São Francisco. In: Barbosa J.S.F., Mascarenhas J.F.M., CorrêaGomes L.C., Domingues J.M.L. (eds.) Geologia da Bahia. Pesquisa e Atualização de Dados, Salvador, CBPM, 2, p. 33-86.

Hoffman P.F., Dewey J.F., Burke K. 1974. Aulacogens and their genetic relation to geosynclines with a Proterozoic example from Great Slave Lake, Canada: In: Dott R.H. \& Siever R.H. (eds.) Modern and Ancient Geosynclinal Sedimentation. Tulsa Society of Economic Paleontologists and Mineralogists, Special Publication, 19, p. 38-55.

Israel S.A., Kennedy L.A., Friedman R.M. 2013. Strain partitioning in accretionary orogens, and its effects on orogenic collapse: Insights from western North America. Bulletin of the Geological Society of America, 125:1260-1281.

Jardim de Sá E.F., Bartels R.L., Brito-Neves B.B., McReath I. 1976. Geocronologia e o modelo tectonomagmático da Chapada Diamantina e do Espinhaço Setentrional, Bahia. In: SBG, Congresso Brasileiro de Geologia, 29, Anais, p. 205-227.

Jolivet L., Daniel J.M., Fournier M. 1991. Geometry and kinematics of the Alpine Corsica. Earth and Planetary Science Letters, 104:278-291.

Lagoeiro L.E. 1990. Estudo das deformações nas seqüências carbonáticas do Grupo Una na região de Irecê, BA. Dissertação de Mestrado, Departamento de Geologia, Universidade Federal de Ouro Preto, Ouro Preto, 150 p.

Letouzey J. 1990. Fault reactivation, inversion and fold-thrust belt. In: Letouzey J. (ed.) Petroleum and Tectonic Mobile Belts. Editions Technip, Paris, p. 101-128.

Marshak S., Alkmim F.F., Whittington A., Pedrosa-Soares A.C. 2006. Extensional collapse in the Neoproterozoic Aracuaí Orogen, eastern Brazil: a setting for reactivation of asymmetric crenulation cleavage. Journal of Structural Geology, 28:129-147.

McDougall I. \& Harrison T.M. 1999. Geochronology and Thermochronology by the 40Ar/ 39Ar Method. Oxford, Oxford University Press, 269 p.

Misi A., Kaufman A.J., Azmy K., Dardenne M.A., Sial A.N., Oliveira T.F. 2011. Neoproterozoic successions of the São Francisco Craton, Brazil: the Bambuí, Una, Vazante and Vaza Barris/Miaba groups and their glaciogenic deposits. Geological Society of London (Memoirs), 36:509-522.
Nier A.D. 1950. A determination of the relative abundance of the isotopes of carbon, nitrogen, oxygen, argon, and potassium. Physical Reviews, 77:789-783.

Okudaira T., Takechita T., Hara I., Ando J. 1995. A new estimate of the conditions for transition from basal $<a>$ to prism [c] slip in naturally deformed quartz. Tectonophysics, 250:31-46.

Passchier C.W. \& Trouw R.A.J. 2005. Microtectonics. Berlin, Edition Springer, $366 \mathrm{p}$.

Pedrosa-Soares A. \& Alkmim F.F. 2011. How many rifting events preceded the development of the Araçuaí-West Congo orogen? Geonomos, 2:244-251.

Pedrosa-Soares A.C., Noce C.M., Wiedemann C.M., Pinto C.P. 2001. The Araçuaí-West-Congo Orogen in Brazil: an overview of a confined orogen formed during Gondwanaland assembly. Precambrian Research, 1-4:307-323.

Pedrosa-Soares A.C., De Campos C.P., Noce C., Silva L.C., Novo T., Roncato R., Medeiros S., Castañeda C., Queiroga G., Dantas E., Dussin I., Alkmim F. 2011. Late Neoproterozoic-Cambrian granitic magmatism in the Araçuaí orogen (Brazil), the Eastern Brazilian Pegmatite Province and related mineral resources. Geological Society, 350:25-51

Pimentel M.M., Machado N., Lobato L.M. 1994. Geocronologia U/ $\mathrm{Pb}$ de rochas graníticas e gnáissicas da região de Lagoa Real, Bahia, e implicações para a idade da mineralização de urânio. In: SBG, Congresso Brasileiro de Geologia, 38, Boletim de Resumos Expandidos, p. 389-390.

Poirier J.P. \& Guillopé M. 1979. Deformation induced recrystallization of minerals. Bulletin of Mineralogy, 102:67-74.

Renne P.R. \& Norman E.B. 2001. Determination of the half-life of 37Ar by mass spectrometry. Physical Review, C63:1-3.

Renne R.P., Deino A.L., Hames W.E., Heizler M.T., Hemming S.R., Hodges K.V., Koppers A.A.P., Mark D.F., Morgan L.E., Phillips D., Singer B.S., Turrin B.D., Villa I.M., Villeneuve M., Wijbrans J.R. 2009. Data reporting norms for ${ }^{40} \mathrm{Ar} /{ }^{39} \mathrm{Ar}$ geochronology. Quaternary Geochronology, 45:346-352.

Renne P.R., Knight K.B., Nomade S., Leunoy K.N., Lou T.P. 2005. Application of deuteron-deuteron (D-D) fission nêutrons ${ }^{40} \mathrm{Ar} /{ }^{39} \mathrm{Ar}$ geochronology. Applied Radiation and Isotopes, 62:25-32.

Rey P., Vanderhaeghe O., Teyssier C. 2001. Gravitational collapse of the continental crust: definition, regimes and modes. Tectonophysics, 342:435-449.

Santos-Pinto M.A.S., Peucat J.J., Martin H., Sabaté P., 1998. Recycling of the Archaean continental crust: the case study of the Gavião Block, Bahia, Brazil. Journal of South American Earth Science, 11:487-498.

Sengör A.M.C., Burke K., Dewey J.F. 1978. Rifts at high angles to orogenic belts: tests for their origin and the Upper Rhine Graben as an example: American Journal of Science, 278:24-40.

Silva C.M.T. 2010. Os sistemas transcorrentes da porção sudoeste do Orógeno Araçuaí e norte da Faixa Ribeira: geometria e significado tectônico. Tese de Doutorado, Universidade Federal de Ouro Preto, Ouro Preto, 221 p.

Simpson C. 1986. Fabric development in brittle-to-ductile shear zones. Pure Applied Geophysics, 124:269-288.

Steiger R.H. \& Jäger E. 1977. Subcommission and Geochronology: convention and the use of decay constant in geo- and cosmochronology. Earth and Planetary Science Letters, 36:359-362.

Stonner R.W., Schoeffer O.A., Katcolf S. 1965. Half-lives of argon-37, argon-39, and argon-42. Science, 148:1325-1328. 
Teixeira L. 2005. Projeto Ibitiara-Rio de Contas. Relatório Temático de Litogeoquímica. Convênio CPRM/CBPM, 33p.

Teixeira L. 2008. Projeto Barra-Oliveira dos Brejinhos. Relatório Temático de Litogeoquímica. Convênio CPRM/CBPM, 29p.

Teixeira L.R. 2000. Projeto Vale do Paramirim. Relatório Temático de Litogeoquímica. Salvador, CPRM/CBPM, 35 p.

Turpin L., Maruèjol P., Cuney M. 1988. U-Pb, Rb-Sr and Sm-Nd chronology of granitic basement, hydrotermal albitites and uranium mineralization, Lagoa Real, South Bahia, Brazil. Contributions to Mineralogy and Petrology, 98:139-147.

Valeriano C.M., Tupinambá M., Simonetti A., Heilbron M., Almeida J.C.H., Eirado L.G. 2011. U-Pb LA-MC-ICPMS geochronology of Cambro-Ordovician post-collisional granites of the Ribeira belt, southeast Brazil: Terminal Brasiliano magmatism in central Gondwana supercontinent. Journal of South American Earth Sciences, 32:416-428.
Vanderhaeghe O. \& Teyssier C. 2001. Crustal-scale rheological transition during late-orogenic collapse. Tectonophysics, 335:211-228.

Vasconcelos P.M., Onoe A.T., Kawashita K., Soares A.J., Teixeira W. 2002. ${ }^{40} \mathrm{Ar} /{ }^{39} \mathrm{Ar}$ geochronology at the Instituto de Geociências, USP: instrumentation, analytical procedures, and calibration. Anais da Academia Brasileira de Ciências, 74:297-342.

Wang C., Xiao P.X., Yu H.Y., Liu L., Liang W.T., Cao Y.T., Meert J.G. 2014. Geochemical and geochronologic constraints for Paleozoic magmatism related to the orogenic collapse in the QimantaghSouth Altyn region, northwestern China. Lithos, 202-203:1-20.

Ziegler P.A. 1983. Inverted basins in the Alpine foreland. In: Baily A.W. (ed.) Seismic expression of structural styles- A picture and work areas. American Association of Petroleum Geologists Bulletin, 3, p. 331-332

Arquivo digital disponível on-line no site www.sbgeo.org.br 